\title{
Long-term History in a Moroccan Oasis Zone: The Middle Draa Project 2015
}

\author{
David J. Mattingly, ${ }^{a}$ Youssef Bokbot, ${ }^{b}$ Martin Sterry, ${ }^{f}$ Aurelie Cuénod, ${ }^{a}$ Corisande Fenwick, ${ }^{c}$ Maria Carmela Gatto, ${ }^{a}$ \\ Nick Ray, ${ }^{d}$ Louise Rayne, ${ }^{a}$ Katrien Janin, ${ }^{e}$ Andrew Lamb, ${ }^{a}$ Niccoló Mugnai ${ }^{a}$ and Julia Nikolaus ${ }^{a}$ \\ a University of Leicester \\ djm7@le.ac.uk;ac565@le.ac.uk;mc95@le.ac.uk;ler14@le.ac.uk;awl5@le.ac.uk;nm277@le.ac.uk; \\ jsni3@le.ac.uk \\ b Institut National des Sciences de l'Archéologie et du Patrimoine \\ bokbotyoussef@yahoo.fr \\ c University College London \\ c.fenwick@ucl.ac.uk \\ d University of Oxford \\ nicholas.ray@classics.ox.ac.uk \\ e University of Cambridge \\ kgrj2@cam.ac.uk \\ f University of Durham \\ martin.j.sterry@dur.ac.uk
}

\section{Abstract}

This article describes the research questions and presents the initial AMs dates of the Middle Draa Project (southern Morocco), a collaborative field survey project between the University of Leicester and the Institut National des Sciences de l'Archéologie et du Patrimoine (INSAP) of Morocco. Starting from a very low baseline of past archaeological research in this pre-desert valley, the overall objective of the project is to establish the extent, character and chronology of the rich archaeology of the Wadi Draa. The results presented here detail a hitherto unknown phase of major occupation in the Draa in the 4th-6th centuries AD evidenced by complex hilltop settlements and extensive cairn cemeteries (an initial typology is presented). A second medieval phase comprised major urban centres that are contemporary with the Almoravid and Almohad periods of Moroccan history. Alongside these urban centres, there are the remains of substantial mudbrick oasis settlements and irrigation and field-systems of a contemporary date. A key contribution of this paper concerns the construction of an outline chronology based upon initial analysis of the ceramics collected, but crucially supplemented and supported by a major program of AMs dating. The remote sensing and field survey data collected by the project enable us to develop some hypotheses concerning the long-term history of this important oasis valley.
Keywords

Protohistory - Islamic archaeology - landscape archaeology radiocarbon dating - irrigation

\section{Résumé}

Cet article présente le cadre du projet de reconnaissance intitulé "Middle Draa Project" (dans le sud du Maroc) et en donne les premières datations radiocarbones. Ce projet fait l'objet d'une collaboration entre l'Université de Leicester (RoyaumeUni) et l'Institut National des Sciences de l'Archéologie et du Patrimoine marocain (INSAP). Se basant sur un très faible volume de recherches archéologiques préalables dans cette vallée pré-désertique, l'objectif général du projet est de déterminer l'abondance, la nature et la chronologie des nombreux vestiges archéologiques présents dans la région de l'oued Draa. Les résultats présentés dans cet article détaillent une importante phase d'occupation, jusqu'à présent inconnue, entre le $4^{\text {ème }}$ et le $6^{\text {ème }}$ siècle de notre ère. Elle est caractérisée par de complexes villages perchés et de vastes cimetières de cairns, dont nous donnons une typologie préliminaire. Il existe ensuite une deuxième phase médiévale comprenant de grands centres urbains contemporains des périodes Almoravides et Almohades de l'histoire marocaine. Datant de la même époque se trouvent par ailleurs dans l'oasis d'importants restes de villages en brique crue et de systèmes de champs et d'irrigation. L'une des contributions majeures de cet article concerne l'élaboration d'une trame chronologique à partir de l'analyse préliminaire de la 
poterie, mais surtout complémentée et supportée par un important programme de datations radiocarbones. Les données recueillies par télédétection et reconnaissance sur le terrain nous permettent de proposer quelques hypothèses quant à l'histoire de cette importante vallée.

\section{Introduction}

This article describes the research questions and presents the initial AMs dates of the Middle Draa Project, a collaborative study between the University of Leicester and the Institut National des Sciences de l'Archéologie et du Patrimoine (INSAP) of Morocco. Starting from a very low baseline, the overall objective of the project is to establish the extent, character and chronology of the rich archaeology of the Wadi Draa, located in southern Morocco (Fig. 1). In this article we focus upon building and characterising the chronology for the region based on a set of new radiocarbon dates. The remote sensing and field survey data collected by the project enable us to develop some hypotheses concerning the long-term history of this important oasis valley.
The Wadi Draa runs north-west to south-east for nearly $300 \mathrm{~km}$ from the Anti-Atlas Mountains to the edge of the Sahara proper, before turning to run from east to west for a further $600 \mathrm{~km}$ to reach the Atlantic. The imposing mountain backdrop of the High Atlas and Anti-Atlas ranges to the north provides sufficient snowmelt and rainfall run-off to make the Wadi Draa the only perennial river that runs into the Sahara from the north. However, even prior to the installation of a modern dam near Ouarzazate, it was only in exceptional years that the flow actually reached the ocean c. $900 \mathrm{~km}$ from its headwaters (this most recently happened after the heavy rains in late November 2014 [Jacques-Meunié 1982: 144]). The Middle Draa corresponds to the c. $200 \mathrm{~km}$ sector where the river flows in a wide valley, with extensive oasis development alongside (see Fig. 2). The Draa valley is hemmed in to the east and west by steep escarpments and there are several 'pinch-points' along the valley where access to the next stretch of the valley can be controlled. These effectively divide the oasis into a series of palmerie zones from north-west to south-east: Mezguita, Tinzouline, Ternata, Fezwata, Ktawa and Mhamid (Jacques-Meunié 1982: 143-146 - see Fig. 3). Overall, this is one of the largest

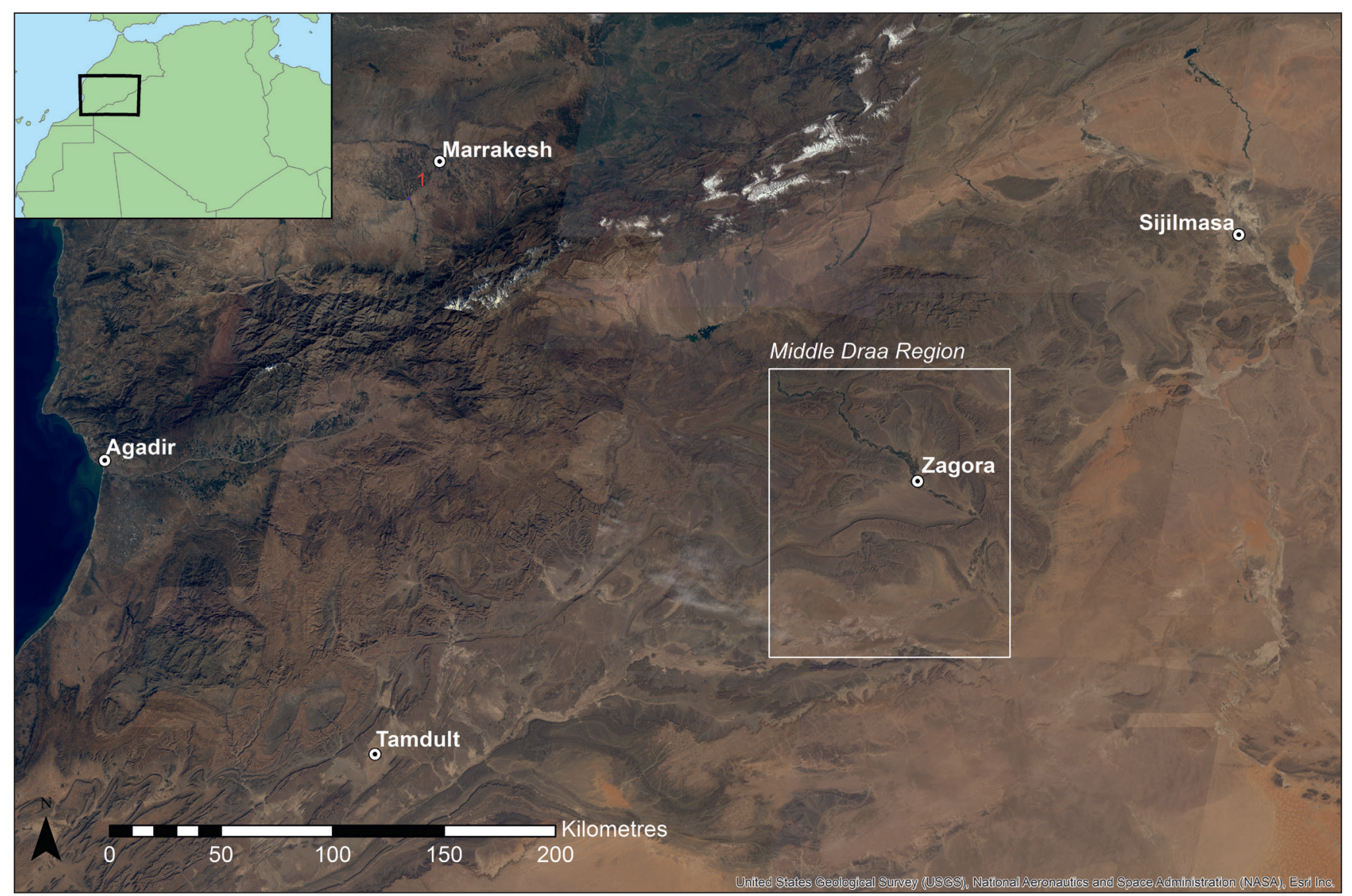

FIGURE 1 Location map showing the Middle Draa Region (imagery courtesy of NASA, ESRI). 


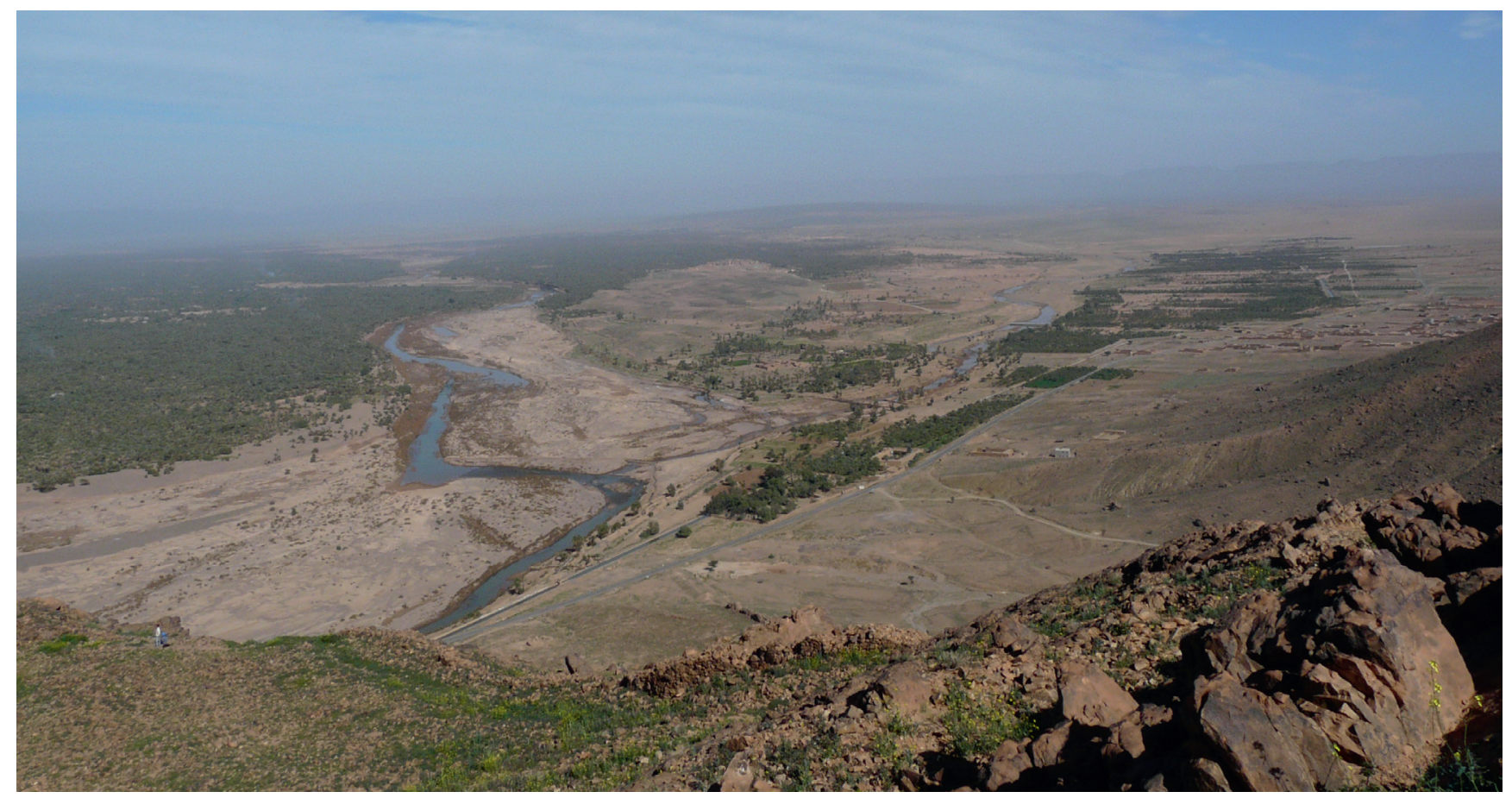

FIGURE 2 The oasis belt of the Wadi Draa to north of Zagora.

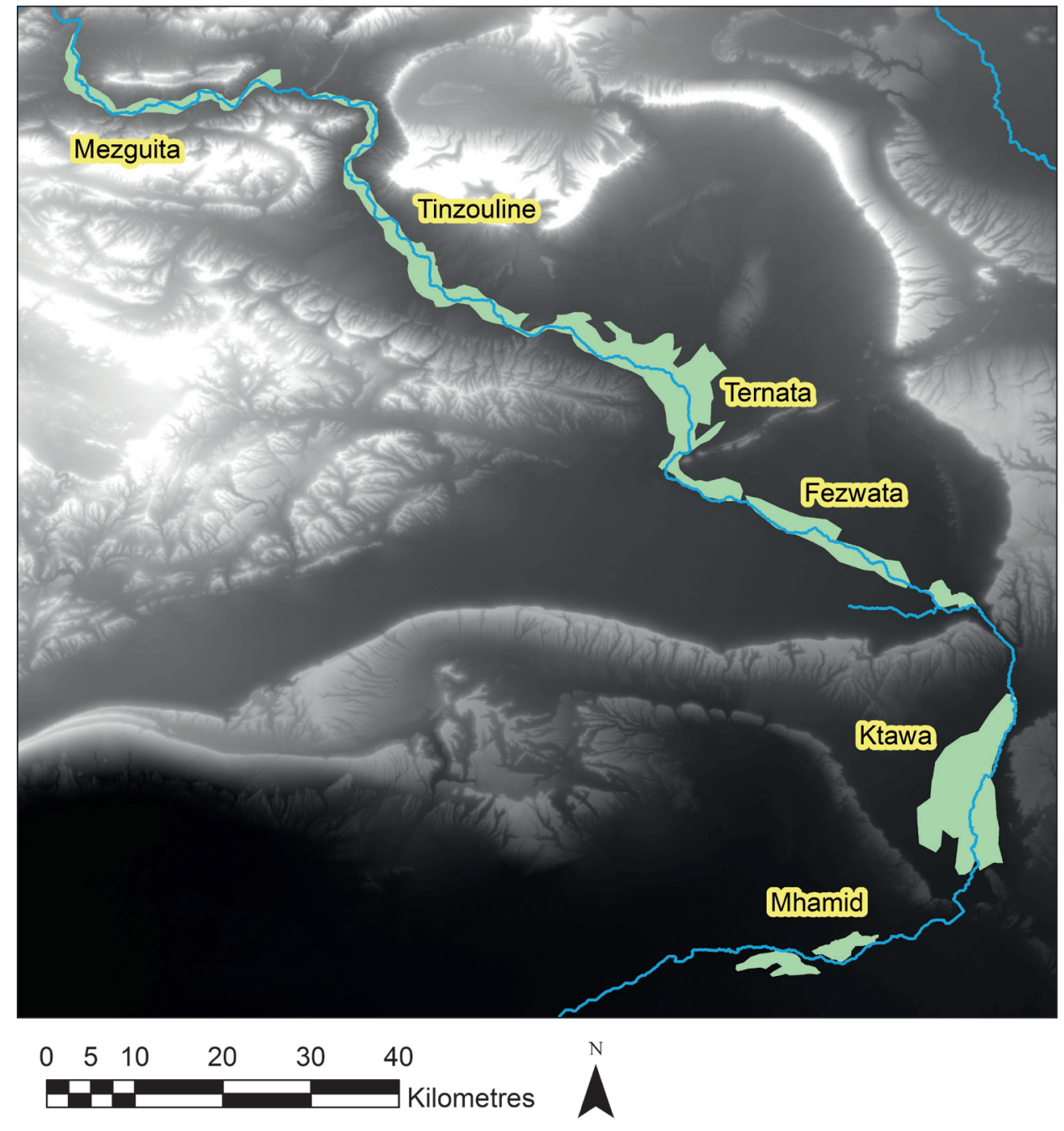

FIGURE 3

The main topographical divisions of the Wadi Draa oasis (DEM: SRTM 1-arcsec collected February 2000. Data available from the U.S. Geological Survey). 
and richest oasis belts in the Sahara. While the great Moroccan centre of medieval Saharan trade was some way to the east at Sijilmasa in the Tafilalat oasis belt (Capel forthcoming; Messier \& Miller 2015), the Wadi Draa has historically been an important secondary corridor for caravans coming from the south to access the Atlas passes and reach Marrakesh.

Despite the fact that it is one of the most important of Saharan oases, the Wadi Draa has not hitherto received detailed archaeological study and comparatively little has been published on its heritage (see Zaïnabi 2004). The largest town, Zagora, lies halfway along the middle section of the wadi at a strategic mountain pass. The Almoravid town and fortress at Zagora were surveyed in the 1950s by Meunié \& Allain (1956) and small-scale excavations were made approximately 30 years ago, but these are not published. There are a number of well-known rock art sites, including a large corpus of horse and rider/hunting scenes with Tifinagh inscriptions close to Tinzouline (for example, Glory et al. 1955; Pichler 2000; Simoneau 1972a; 1972b). Finally, the wadi is well known for its several hundred pisé fortified sites, known as qsur or kasbahs, mostly undated but presumed to be of post-16oo construction. Many of these have been partially planned, but not fully published (Kölbl et al. 2003).

Preliminary satellite remote sensing located extensive archaeological remains of hundreds of sites including hilltop and oasis settlements, cairn cemeteries of pre-Islamic type, irrigation systems and small dispersed settlements. While some of the sites were evidently of medieval and early modern date, some of the hillforts and burial types seemed to represent an earlier phase of habitation and activity and accordingly potentially shed light on key research questions about the nature, economic basis and changes of society of the period 1000 BC-AD 700 . Although the origins of oasis agriculture in the western Sahara are commonly assumed to be later than the Muslim conquest of the Maghrib (for example, Messier \& Miller [2015] describe the Tafilalat plain at Sijilmasa as uncultivated and only seasonally frequented by pastoralists prior to the eighth century $\mathrm{AD}$ ), the sites visible on the satellite images of both the Draa and Tafilalat suggest a longer and more complex history of settlement. The majority of sites located on the satellite imagery of the Draa lie within a few kilometres of the oasis belt, and cairn cemeteries in particular are located closest to some of the most heavily cultivated parts of the wadi today. The fortified pisé villages (kasbahs) are generally located close to or within modern villages and are clearly the direct precursors to the modern-day settlement pattern, but here and there in the valley there are substantial areas of abandoned gardens and mudbrick structures and fortified buildings (qsur) visible beneath drifting dunes. Some of the hillfort sites seemed directly comparable with sites of the first millennium BC and early first millennium AD elsewhere in North Africa and the Sahara (Morizot 1997; Mattingly 2003).

The overall scope of the project involves carrying out survey between Agdz and Mhamid (the northern and southern extremities of the Middle Draa oasis belt), with a desire to sample as wide a range of site types as possible and to include representative examples of all periods. Since the project is informed by analysis of satellite imagery and preliminary identification of many sites visible as standing monuments on the imagery, its primary chronological focus is thus on the (proto-)historical periods, rather than deep prehistory. However, the traces of lithics and rock art are being recorded whenever encountered and it is anticipated that the project will also build up important records of prehistoric activity in the region. A key desideratum is to establish a baseline on the regional chronology, both through direct study of ceramic material collected from the sites visited, but also supported by a programme of absolute dating of organic materials extracted from walls, surfaces and small sondages at many of these sites. Following on from the previous work by Mattingly (2003; 2013) in southern Libya on a Saharan civilisation called the Garamantes, a starting point for the new project was to assess whether southern Morocco might also yield evidence of extensive oasis development in the Early Historic period. The wide distribution of burial tumuli and hilltop settlements of several distinctive morphologies throughout the Draa valley encouraged the view that this was a hypothesis that could be tested by closer archaeological examination of these and related sites. A further important objective was to carry out on-the-ground evaluations of sites that we had already identified to be undergoing (or at high risk of) damage. This aspect of the work also relates to a parallel project on Endangered Archaeology in the Middle East and North Africa (EAMENA). Where such damage is confirmed our Moroccan-UK project has engaged with local agencies and interested parties to raise awareness of the problems and to enhance protection.

\section{Methodology}

The overall aim of the fieldwork is to sample a wide range of settlements, funerary monuments, irrigation works and other site types in order to produce a baseline for future archaeological research. To achieve this aim, the survey methodology was designed in response to the nature of archaeological remains in this region, with many upstanding features and little in the way of overlying deposits (our 
methods were in part derived from previous surveys by the authors in the central Sahara [Sterry \& Mattingly 2011]). On the other hand, we recognise that within the modern oasis belt, earlier phases of activity will be to a greater or lesser extent obliterated or overlain by more recent activity. The earliest agricultural development probably lay close to the banks of the Draa river and will most likely be elusive archaeologically. However, sites (funerary areas and hilltop sites) on the periphery of the oasis should give a proxy indication of past activity and settlement within the area covered by modern palm groves.

The preliminary survey of the study zone was conducted through analysis of satellite scenes making use of high resolution imagery available via Google Earth and Bing Maps in combination with Landsat and SRTM data. An initial assessment of sites was made to identify clusters of remains that could be described as preserved landscapes and those areas with a high archaeological potential. These were then narrowed down to a shortlist of c. 60 locations with a broad geographical distribution and a range of site morphologies and topographies. These were made the subject of detailed mapping of all visible archaeological features. This preliminary desk-based survey formed the basis for site visits with locations and tentative plans supplied to the field teams for annotating and augmenting in the field.

Survey strategy on the ground was kept flexible to permit different forms of recording, from brief reconnaissance visits (c. 30 minutes) to more in-depth studies over several days. The following approaches were routinely employed on site by the survey teams, which normally comprised 3-4 individuals:

- A detailed site sheet, recording archaeological features, general description, interpretation, damage and threats, and material culture.

- Photographic recording of features, masonry, viewsheds, etc.

- An annotated site plan.

- A 'structured' collection of all material from one or more $10 \mathrm{~m}^{2}$ circles whose position was fixed via a handheld GPS point.

- A 'grab' collection of diagnostic material and small finds rim sherds, decorated sherds, glazed sherds, beads, etc.

- A 'feature' collection of key groups of material associated with particular features, such as burnt animal bone on offering structures (again located via a GPS point).

- GPS points on significant archaeological features, especially those not clearly visible on satellite imagery, e.g. gates in walls and rock art.

- Opportunistic sampling of organic material embedded into standing structures (mudbrick, pisé, mortar) or exposed occupation layers cut by gullies or rock fall (also located via a GPS point).

- Structure-from-motion recording of distinctive archaeological features (tombs, buildings, irrigation canals, etc.) to create dense point clouds and ${ }_{3} \mathrm{D}$ models. This was facilitated via the use of a self-levelling telescopic camera pole and a wireless connection to a tablet.

- Small-scale excavation in controlled test-pits (max. $1 \times 1 \mathrm{~m}$ ) down to bedrock/natural to obtain stratified organic samples for radiocarbon dating and for potential environmental analysis.

The project database was designed using the AR $\mathrm{K}$ package (ark.lparchaeology.com; Eve \& Hunt 2008). This provides an effective repository for project records and photographs. Additionally the database ties together the collected data with specialist analyses (ceramics, bone, small finds) through associated site codes and through spatial proximity.

\section{Survey Results}

In total, 166 sites have been visited and recorded by the field teams to date in a series of 11 different sub-zones of the Draa. Each site is designated by a three-letter code related to these sub-zones and a three-digit number (thus ZAGoo1 is the upper citadel on the summit of the mountain of Zagora by the modern town where the mission was based).

\section{AMs Radiocarbon Dating}

In order to establish a firmer absolute chronology for the Draa valley and to help refine the ceramic typo-chronology outlined later in this report, the MDP has embarked on a major programme of AMS radiocarbon dating of sites and structures. A total of c. 100 samples for possible dating was obtained from mudbrick, pisé and mortar- and mudbonded stone walls choosing material that relates to the construction of the structures, as well as from numerous small sondages and exploratory trenches that targetted stratified occupation deposits. The samples cover a range of time periods from Early Historic sites such as TINoo1, TINo15, LARoo2, LARoo5/006, to settlements representative of different moments of the long medieval period (ZAGo01/002, LARoo3/004, BOU001/002/003/005/007, etc.) and the early modern era (ZAGo46/047/048). A selection were submitted to the Oxford Radiocarbon Accelerator Unit (Table 2). Of these there were two repeat samples and four failed samples, while three further dates were 
TABLE 1 The survey areas of the Draa defined by three-letter codes. These are arranged in north-west to south-east sequence (see also Fig. 4)

\begin{tabular}{|c|c|c|c|c|c|c|c|c|}
\hline Sub-zone & $\begin{array}{l}\text { Letter } \\
\text { Code }\end{array}$ & Settlement & Funerary & $\begin{array}{l}\text { Irrigation and } \\
\text { Agriculture }\end{array}$ & $\begin{array}{l}\text { Material } \\
\text { Scatter }\end{array}$ & Rock Art & Other & Total \\
\hline $\operatorname{Agdz}$ & AGD & 3 & 1 & & & & & 4 \\
\hline Tamezmoute & TAM & 2 & 2 & & & & & 4 \\
\hline Tinzouline & TIN & 15 & 1 & & & 3 & 1 & 20 \\
\hline Taghmat & TAG & 2 & 1 & & & & & 3 \\
\hline Kasr Tissergate & TIS & 4 & & & & & & 4 \\
\hline Zagora & ZAG & 23 & 15 & & 1 & & 7 & 46 \\
\hline Tamegroute & TMG & 1 & & 2 & 1 & & & 4 \\
\hline Imi n Takat n Draa & TAK & 11 & 3 & 3 & & & 3 & 20 \\
\hline Kasr Tiraf & TIR & 1 & & 1 & & & & 2 \\
\hline Foum Larjam & LAR & 12 & 9 & 1 & & 1 & 6 & 29 \\
\hline Kasr Bounou & $\mathrm{BOU}$ & 17 & 2 & 5 & 6 & & & 30 \\
\hline Total & & 91 & 34 & 12 & 8 & 4 & 17 & 166 \\
\hline
\end{tabular}

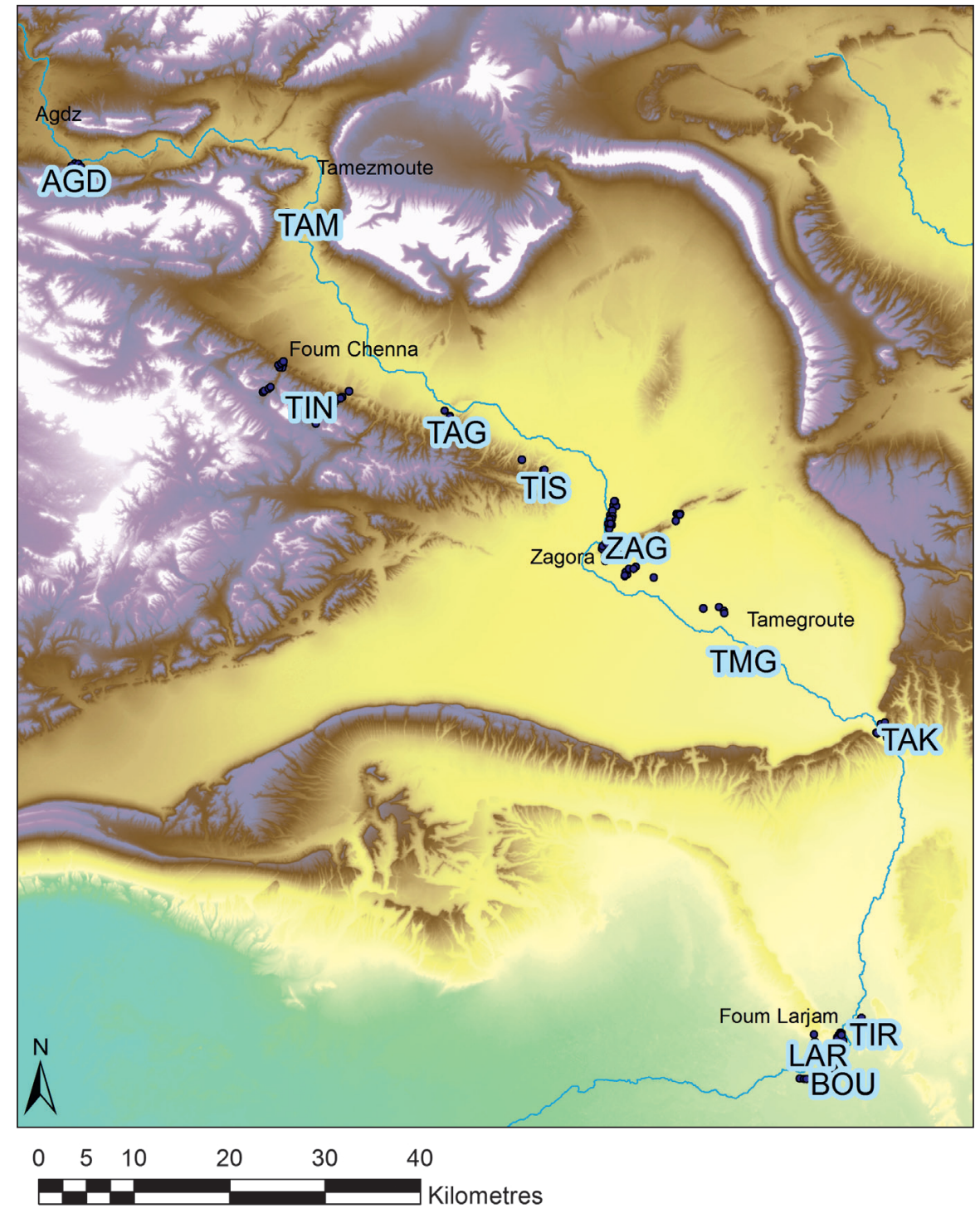

FIGURE 4

The area codes used by the Middle Draa Project mapped in relation to the topography of the Wadi Draa. Sites visited are marked by dots (DEM: SRTM 1-arcsec collected February 200o. Data available from the U.s. Geological Survey). 
TABLE 2 Initial AMS Radiocarbon dates from the MDP arranged by site and chronological order. The results are presented here at $2 \sigma$ and calibrated to the IntCal 13 curve (Reimer et al. 2013) using OxCal 4.2 (Bronk Ramsey 2009)

\begin{tabular}{lllll}
\hline Site/Context & OxA\# & Material (species) & Date BP
\end{tabular}

\section{LARoo 1 Cairn Cemetery}

Surface of tomb from recent looting

LARoo2 Hilltop Settlement

Trench 1, context 1019

Lower occupation layer

Trench 1, context 1016

Upper occupation layer

Same sample as above

Trench 1, context 1015

Abandonment layer

Trench 2, context 1021

Fill of drainage channel

Trench 2, context 1021

Fill of drainage channel

\section{TINo15 Hilltop Settlement}

Trench 2, context 1028

Occupation layer

\section{LARoo5 Cairn Cemetery}

Trench 1, context 1014

Base of burial chamber

\section{TAKoo6 Hilltop Settlement}

Trench 2, context 2012

Occupation layer

Trench 1, context 2010

Occupation layer

TAMoo1 Hilltop Settlement

Trench 1, context 3028

Occupation layer

\section{LARo3 1 Cairn Cemetery}

Surface of offering structure

OxA-33899

Calcined bone (ovicaprid?)

BOUoo2 Oasis Settlement

From SE wall of qasr

OxA-33784

Charcoal (cf. tamarix sp.)

\section{ZAGoo2 Medieval Town}

Trench 1, context 1007 (fabric of mudbrick wall)

From mortar of E gate

From mortar of $\mathrm{W}$ wall of tomb
OxA-33859 Charcoal

OxA-33863 Charcoal (cf. palm)

OxA-33861
Charcoal
$1344 \pm 30$

cal AD 641-765

$1196 \pm 32$

cal AD 713-945

$2649 \pm 28 \quad 894-791$ cal вс

$1638 \pm 27 \quad$ cal AD $339-534$

$1676 \pm 28 \quad$ cal AD $260-422$

$1616 \pm 27 \quad$ cal AD $389-536$

$1504 \pm 28 \quad$ cal AD $432-633$

cal AD 612-679

cal AD 778-994

cal AD 383-536

cal AD 406-542

cal AD 411-542

cal AD 423-557

$1512 \pm 27 \quad$ cal AD $430-615$

$1113 \pm 27 \quad$ cal AD $878-995$

$1023 \pm 26 \quad$ cal AD 971-1115

$992 \pm 26 \quad$ cal AD 989-1151 
TABLE 2 Initial AMS Radiocarbon dates from the MDP arranged by site and chronological order. The results are presented here at $2 \sigma$ (cont.)

\begin{tabular}{|c|c|c|c|c|}
\hline Site/Context & OxA \# & Material (species) & Date BP & Calibrated \\
\hline From mortar of S enclosing wall & $\mathrm{OxA}-325^{21}$ & Charcoal (unknown) & $989 \pm 26$ & cal AD $991-115^{2}$ \\
\hline From tower in E wall & OxA-33864 & Charcoal (cf. tamarix sp.) & $983 \pm 26$ & cal AD $995^{-11} 153$ \\
\hline From mortar in W enclosing wall & OxA-3386o & Charcoal (cf. palm) & $975 \pm 26$ & cal AD 1014-1155 \\
\hline From secondary phase of S enclosing wall & $\mathrm{OxA}-33862$ & Charcoal (cf. tamarix sp.) & $972 \pm 25$ & cal AD 1016-1155 \\
\hline \multicolumn{5}{|l|}{ ZAGoo1 Medieval Town } \\
\hline From mortar of S enclosing wall & OxA-33858 & Charcoal & $974 \pm 25$ & cal AD $1015^{-1155}$ \\
\hline Same sample as above & OxA-33857 & Charcoal & $946 \pm 26$ & cal AD 1026-1155 \\
\hline Trench 2, context 3021 & $\mathrm{OxA}-32372$ & Charred seeds (phoenix & $792 \pm 25$ & cal AD 1210-1275 \\
\hline Abandonment Layer & & dactylifera) & & \\
\hline Trench 1, context 3004 & OxA-33856 & Charred seeds (date) & $688 \pm 26$ & cal AD $1269-1387$ \\
\hline
\end{tabular}

Abandoment Layer

BOUo22 Oasis Settlement

From mudbrick wall of building

OxA-33718 Plant remains (grass)

$969 \pm 37$

cal AD 997-1159

BOUoo1 Oasis Settlement

From mudbrick wall of building

OxA-33783 Plant remains (grass)

$933 \pm 31$

cal AD 1025-1164

TIRoo6 Oasis Settlement

From wall of qasr

OxA-32432 Plant remains (unknown)

$919 \pm 25$

cal AD 1030-1169

LARoo4 Medieval Town

From pisé of S enclosing wall

OxA-32374 Charcoal (unknown)

$878 \pm 25$

cal AD 1046-1221

BOUoo3 Oasis Settlement

From SE wall of qasr

OxA-33823 Charcoal (cf. tamarix sp.)

$870 \pm 26$

cal AD 1046-1245

LARoo3 Extra-urban Settlement

Trench 1, context 2006

OxA-33719 Charcoal

$823 \pm 28$

cal AD 1166-1263

Floor layer

BOUoog Oasis Settlement

From mudbrick wall of building

OxA-33824 Plant remains

$810 \pm 27$

cal AD $1170-1270$

TAKo13 Fortified Granary

From mortar of outside wall

OxA-33853 Plant remains

$365 \pm 26$

cal AD 1450-1634

ZAGo4o Oasis Settlement

From pisé wall

OxA-33866 Charcoal

$307 \pm 24$

cal AD 1493-1649

TAKo16 Pisé Kasbah

From pisé wall

OxA-33854 Charcoal

$243 \pm 24$

cal AD 1528

\section{ZAGo46 Pisé Kasbah}

From pisé wall

OxA-33967 Grass culms

$234 \pm 25 \quad$ cal AD $1639-$ 


\begin{tabular}{|c|c|c|c|c|}
\hline Site/Context & $\mathbf{O x A} \#$ & Material (species) & Date BP & Calibrated \\
\hline \multicolumn{5}{|l|}{ ZAGo42 Oasis Settlement } \\
\hline From pisé wall & $\mathrm{OxA}-33867$ & Seeds (date palm) & $205 \pm 24$ & cal AD 1649- \\
\hline \multicolumn{5}{|l|}{ ZAGo48 Pisé Kasbah } \\
\hline From pisé wall & OxA-33901 & Charcoal (palm) & $195 \pm 29$ & cal AD $1648-195^{\circ}$ \\
\hline From pisé wall & OxA-33868 & Plant remains & $128 \pm 24$ & cal AD $1678-1940$ \\
\hline \multicolumn{5}{|l|}{ TAKoo 1 Pisé Kasbah } \\
\hline From a mudbrick wall & OxA-3390o & Plant remains & $129 \pm 29$ & cal AD $1675^{-1942}$ \\
\hline \multicolumn{5}{|l|}{ LARoo6 Hilltop Settlement } \\
\hline From external wall (intrusive) & $\mathrm{OxA}-33898$ & Plant remains & $104 \pm 28$ & cal AD 1692-1935 \\
\hline \multicolumn{5}{|l|}{ TAKoo4 Medieval Town } \\
\hline From S boundary wall (intrusive) & $\mathrm{OxA}-33^{8} 5^{\circ}$ & Sheep/goat pellet & & Post-1950 \\
\hline \multicolumn{5}{|l|}{ ZAGo22 Oasis Settlement } \\
\hline Trench 1 (intrusive) & $\mathrm{OxA}-33865$ & Seeds (geraniaceae family) & & Post-1950 \\
\hline
\end{tabular}

evidently from intrusive material (OxA-33850, OxA-33865 and $\mathrm{OxA}-33898)$. The initial dates demonstrate the efficacy of the sampling methods being employed and are presented here by site (arranged chronologically from earliest to latest). Inevitably with this first group of dates there is a possibility that further work will refine our conclusions, but we would emphasise that, apart from a very few noted exceptions, they are in line with other indications of relative dating ceramic material, site morphology, construction technique. We have made a conscious decision to concentrate on dating a greater number of sites rather than taking multiple samples from fewer sites as we consider that it is the aggregate dating from multiple sites that will give a higher degree of confidence in constructing a regional chronology. The dates will be discussed further in relation to the chronological periods to which they relate in the following sections.

\section{Palaeolithic and Early Holocene Occupation}

Early prehistoric human occupation in the Draa is attested by chance surface finds across the region, both in the valley and in the adjacent mountains. The earliest evidence, an Oldowan pebble chopper and an Acheulean proto-hand axe, both found in the valley close to Tamegroute (TMG), dates to the Lower Palaeolithic age. Middle Palaeolithic finds are widespread, but particularly important was a well-preserved Aterian point, again from the Tamegroute area (see also Letan 1972 for evidence along the Draa valley). No Upper Palaeolithic or Epipalaeolithic industries were found during the first field season.

Early Holocene evidence consists of a similarly sparse distribution of lithic flakes and debitage of demonstrably more recent age than the highly patinated Palaeolithic material. These included a few flint blades with lateral retouched notches. In the Kasr Bounou area (воU) two small and quite weathered pottery sherds were rockerimpressed with a comb forming a packed zigzag pattern. Both may be as early as the Neolithic period, although it is impossible to confirm this at this stage of the investigation.

\section{Funerary Landscapes}

The Wadi Draa is notable for the number and density of its non-Muslim burial monuments, primarily various forms of circular tumuli (for previous work, see Bokbot 1991; Jacques-Meunié 1958). Mapping of these from available satellite imagery had identified a total of at least 5600 cairn tombs in the Ktawa region alone before the season began (Fig. 5). Work was carried out in three zones: LAR, TAK and ZAG with the aim of establishing a basic typology of the monuments. The circular cairns have been divided into four main types (type 1: low cairn; type 2: mound cairn; type 3: drum cairn; type 4: corbel cairn), with a range of sub-types (Fig. 6). The size of the largest monuments 


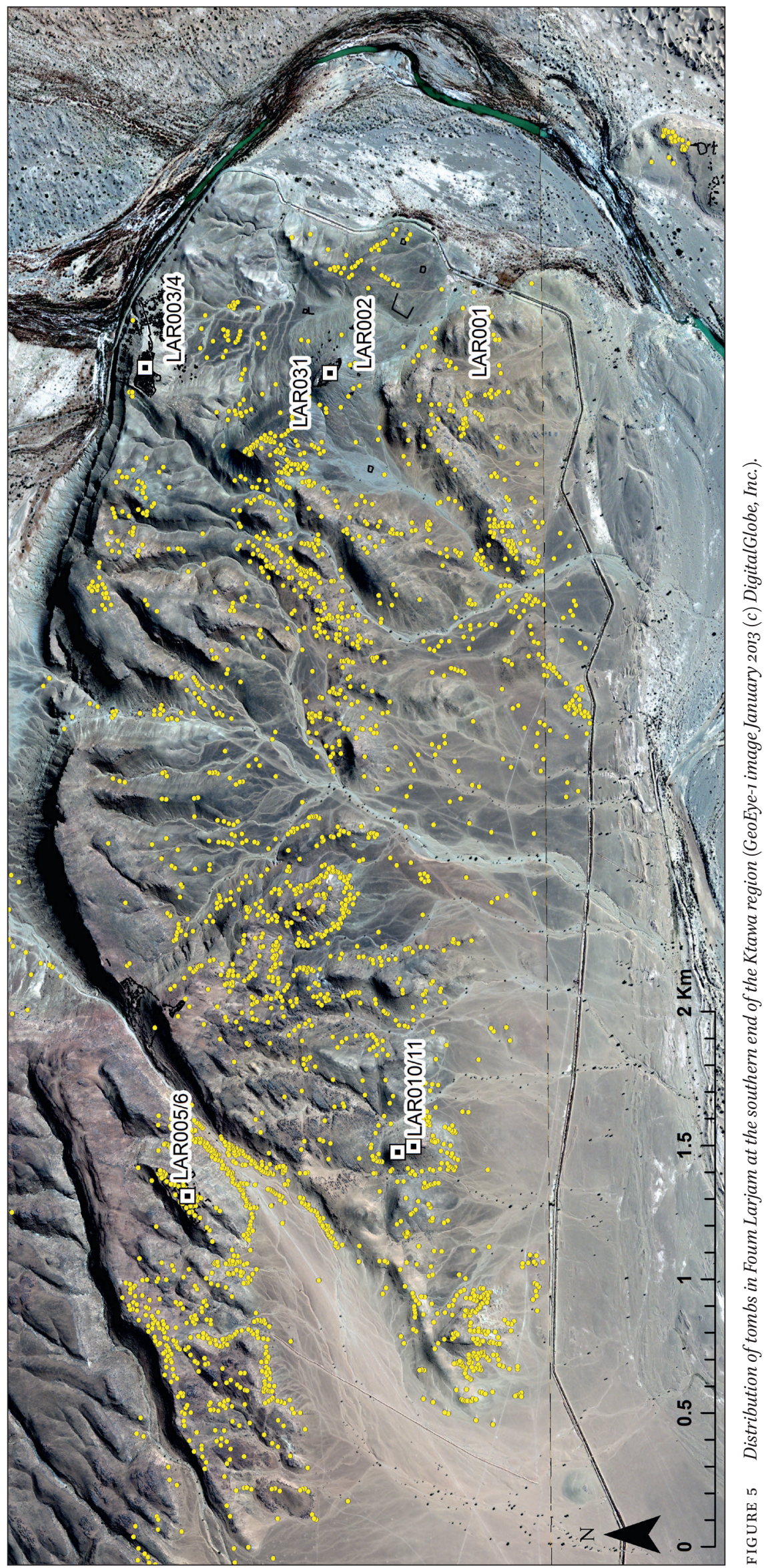



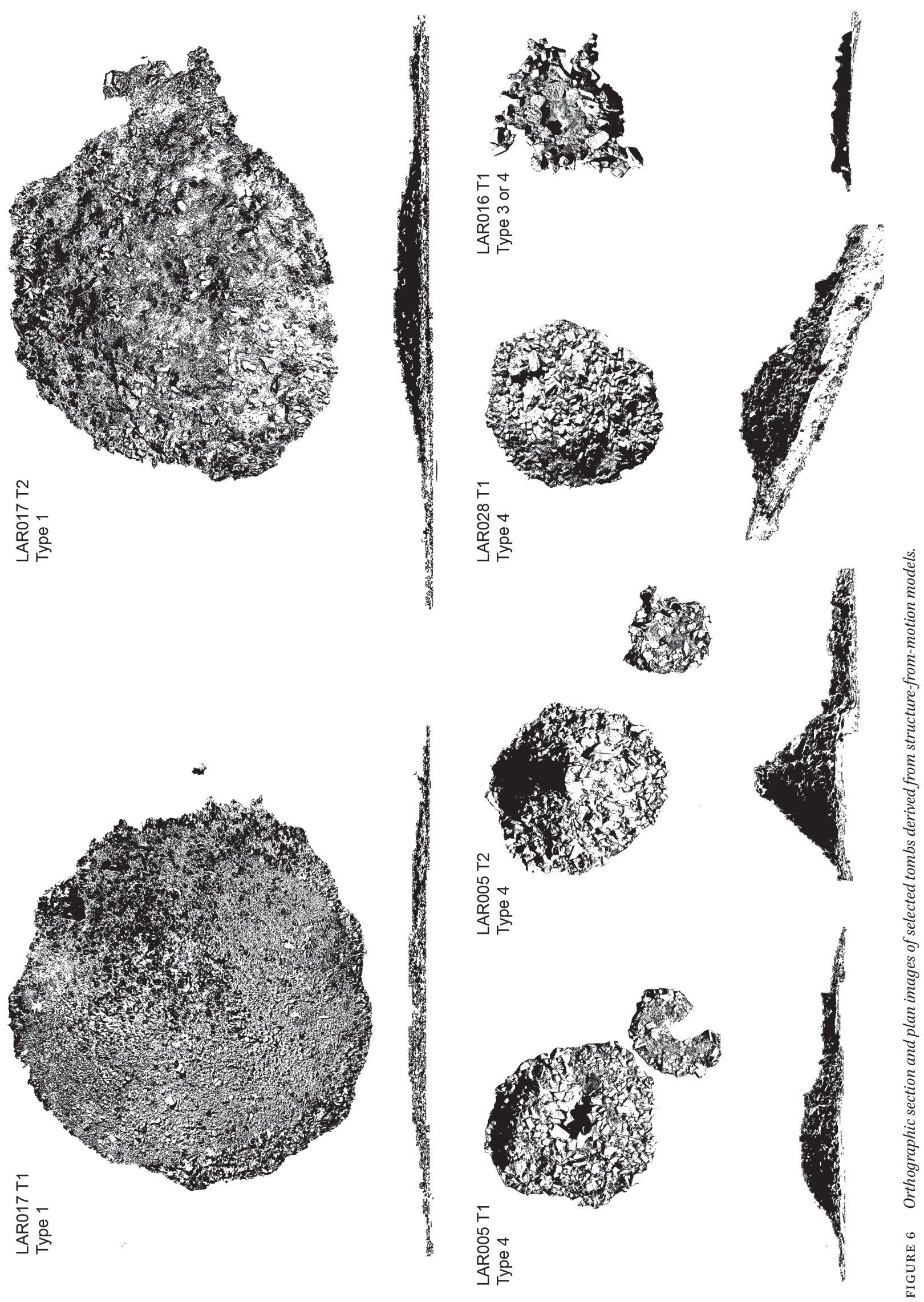
is impressive. Mound cairns can be up to $10 \mathrm{~m}$ in diameter and stand up to $2 \mathrm{~m}$ high, while the conical corbelled cairns can reach more than $3 \mathrm{~m}$ in height and $6 \mathrm{~m}$ in diameter. Some of these cairns are accompanied by small structures or platforms placed on the east side (most commonly to the south-east) of the tomb. These are believed to be offering structures on account of the traces of many fragments of small animal bone (some burnt) found in association with some of these. They were built in a variety of shapes, some rectilinear, others curvilinear. There are also at least two types of rectangular or oval burials (type 5 : simple oval mound; type 6: more elaborate rectangular markers), both are probably Islamic (or perhaps Jewish) and of medieval or later date, again with sub-types depending on whether they had marker stones placed at either end. The typology will need further extension to cover the range of marabout tombs (type 7). Finally, a crescent monument with a span of at least $107 \mathrm{~m}$ has been observed from satellite imagery at Foum Larjam. Similar examples are known from southern Morocco and Western Sahara and these would suggest that the Draa example is probably of late Neolithic date.

Those tombs suspected of being of pre-medieval date were only rarely associated with pottery or other material culture (grinding stones were found near some). Almost all have been heavily robbed at some point in the past. Samples from two examples returned radiocarbon dates of 894-791 cal BC for a mound cairn from LARoo1 and cal AD 406-542 for an excavated corbel cairn from LARoo5 (Fig. 7). In combination with the crescent monument,

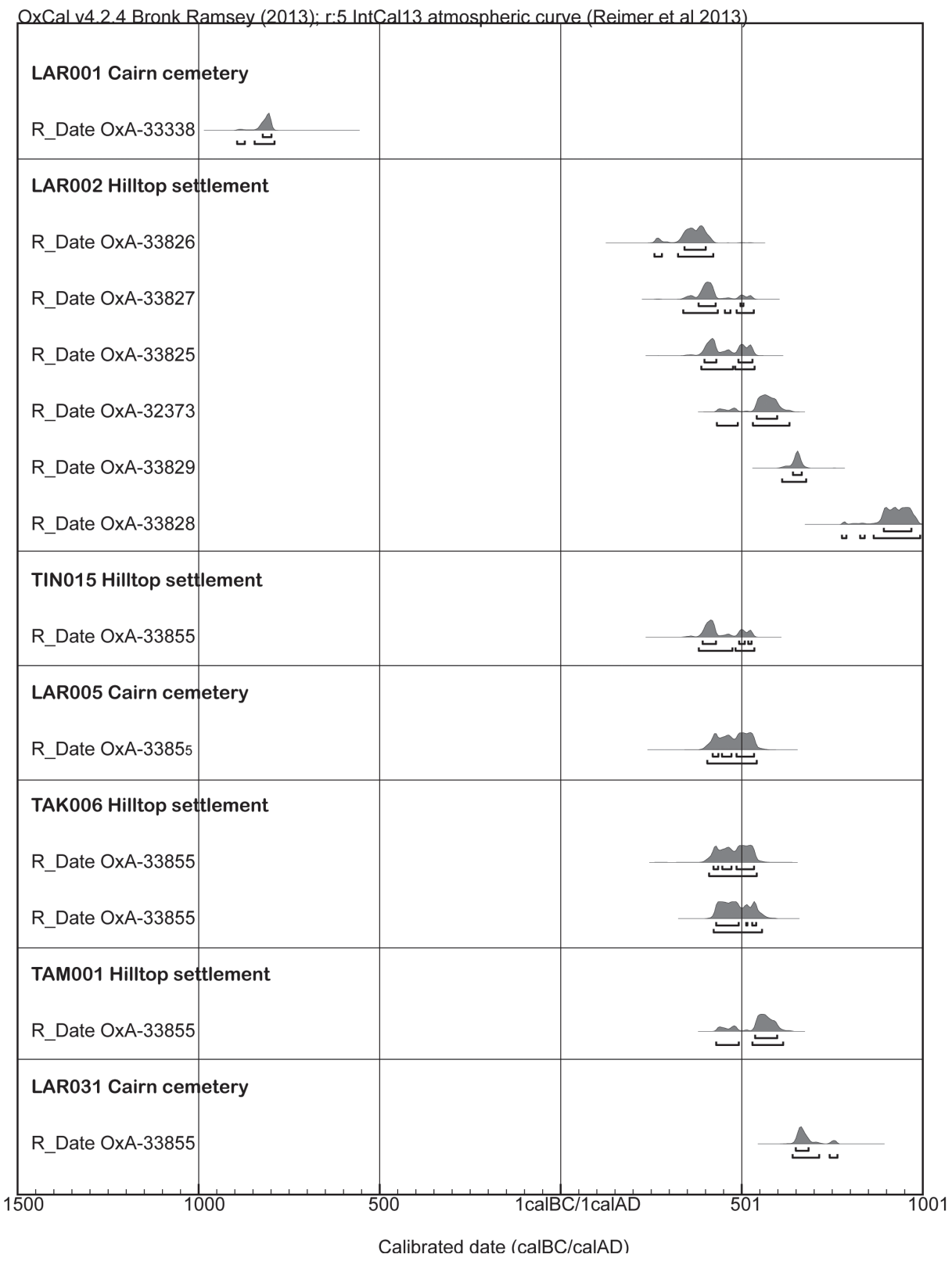

FIGURE 7

Radiocarbon dates from early historic sites. 
these results indicate the long-term use of Foum Larjam as a burial landscape. Calcined animal bone recovered from an offering structure to the south-east of a corbel cairn in LARo31 was dated to cal AD 641-765 and suggests that these burial traditions were still respected in the seventh century if not later. This is paralleled by evidence from Fazzan, Libya of crouched burials as late as the ninthtenth centuries (Mattingly et al. forthcoming). It is clear that the Muslim conquest of the Maghrib did not equate to a sudden change in burial practices everywhere.

Painted scenes have recently been reported from the interior walls of a corbelled tomb in the Foum Larjam area (Zaïnabi 2004: 40), adding to the interest and importance of the funerary monuments. The images of human figures with lances and animals strongly resemble the famous painted plaques from the funerary chapels at Jorf Torba to the east of the Draa in western Algeria (Reygasse 1950: 104-108; Camps 1984: 208-212; Lihoreau 1993). The painted Foum Larjam tomb was relocated and the presumed late antique date confirmed during our 2016 season. Work on the pre-Islamic cemeteries will be a major component of the project as it develops.

\section{Early Historic Hilltop Settlements}

A very distinctive category of sites in the Wadi Draa comprises a range of perched hilltop sites that seem to span a period from the early first millennim $\mathrm{AD}$ to the seventeenth century. Some of these appear to have been classic fortified granaries filled with multiple standard storage units with small low doors (we have an AMs date for one of these - TAKo13, suggesting construction in the fifteenth to seventeenth centuries AD). The largest site (ZAGoo1 perched on the top of Jabal Zagora is a medieval town (see below). Others may have served as temporary refuges for oasis dwelling communities in times of unrest. Yet others seem likely to have been among the earliest nucleated settlements of the Draa region. Our initial research and AMs radiocarbon dating programme on these hilltop sites has identified a group dating to the early-mid-first millennium $\mathrm{AD}$, characterised by multiple enclosures and stonebuilt architecture (Fig. 8) with a consistent handmade ceramic assemblage with many cordon decorated vessels. We shall illustrate this by reference to a few key examples.

\section{The Northern and Central Zones of the Middle Draa: Foum Chenna (TINoor), Assif Ouiggane (TINo15),} TAMooı, TAKoo6

The wadi emerging from the hills to the west of Tinzouline at Foum Chenna is famous for a dense concentration of rock art on the vertical rock faces lining its 'entrance' (Fig. 9, TINo12). Another wadi a short distance to the south has also yielded similar engravings on its rock walls (TINo27/028) (Simoneau 1972b: 27-36). At both sites, there is an emphasis on imagery of the horse and of armed horsemen (typically with a small circular shield and lance), though other animals feature, such as ibex, dogs, lions, ostriches, camels etc. Although both sites have been described before (cf. Simoneau 1972b: 29), scholars have not previously noted that each rock art complex is closely connected with an associated fortified hilltop site (Fig. 10, TINoo1 at Foum Chenna and TINo15 at the more southerly site of Assif Ouiggane). On a flat-iron hill facing the Draa, TINoo1 is a classic perched site protected by a series of substantial drystone walls, each with a single gateway. The walled core of the site comprises a series of enclosures and c. 8-1o buildings leading off a central alleyway that ran to the highest point of the hill, which was left empty apart from a possible cairn at the top. There are at least two phases of construction visible: the earliest consists of loosely coursed boulders and the second of drystone slab masonry. A number of horse engravings were found built into the structures of the settlement implying a close relation between the rock art and the people of this site.

TINo15 shares some similarities of layout, with a lower outer enclosure that contained a few vestigial traces of structures and a middle zone entered through a gate in a second wall, where most of the habitation seems to have been concentrated. A central road again led up through the settlement to a third area on the highest part of the site that was empty of structures, but which was covered in rock art on natural rock surfaces and many boulders. As at TINoo1, the vast majority of the images depict horses (and sometimes their riders). The highly structured placement of the rock art imagery in relation to the settlement strongly supports the view that the two activities were at least in part contemporaneous.

Further to the north, TAMoor is a hilltop settlement with an almost identical position and layout (but with no rock art). Progression up the hill is interrupted by a series of four further large walls, each punctuated by a gate, serving to divide the hillside into large enclosures in which livestock were possibly kept. The main occupation site is at the uppermost (western) end and surrounded by an enceinte. Within the main settlement, the structures were built against one another in four or five clusters in the lower (eastern) part; above this where the bedrock is more prominent, the structures were smaller and situated independently, and more sparsely, with some of them appearing to have served as storage units. 

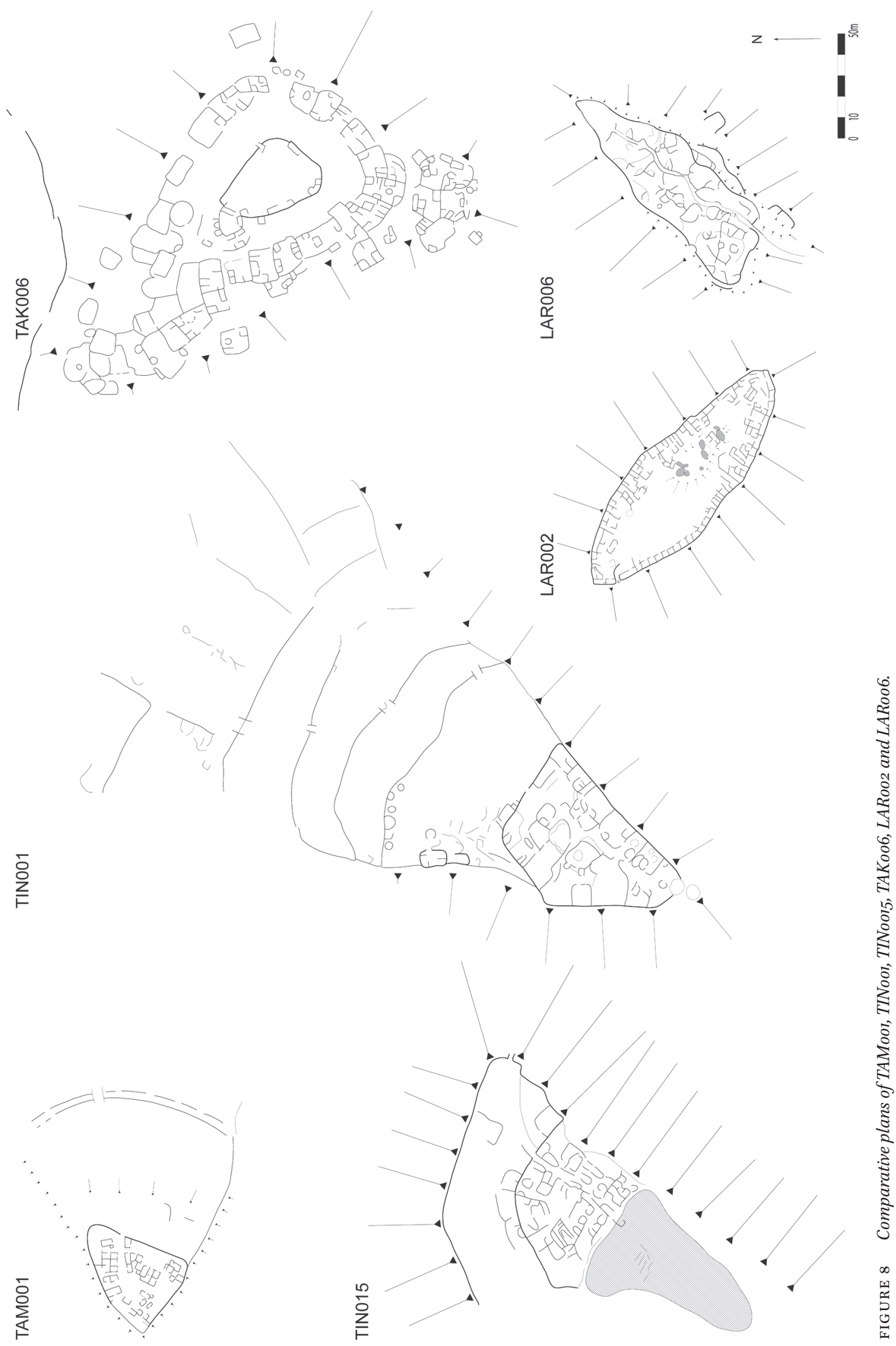

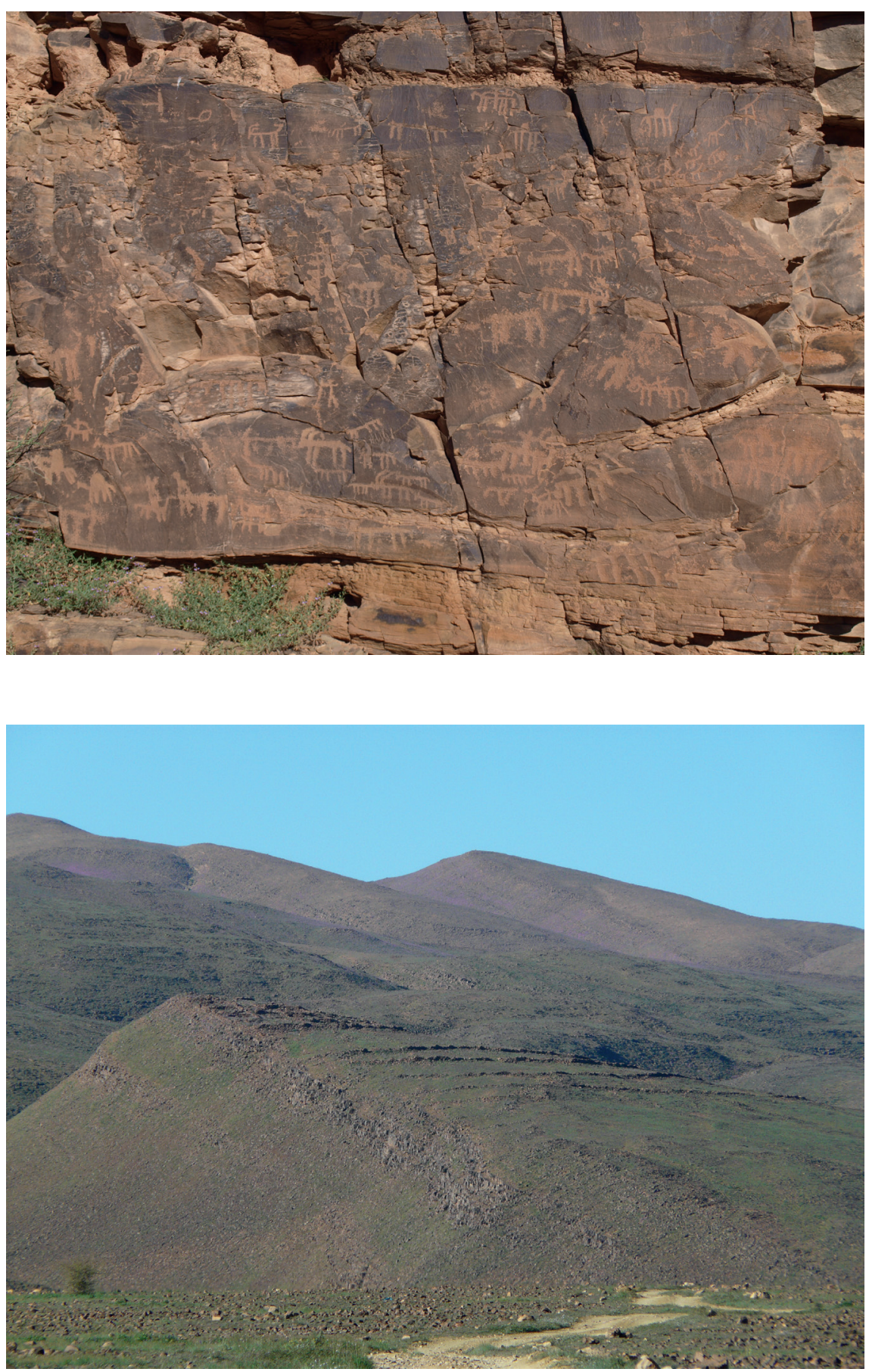

FIGURE 9

Example of horse and rider rock art found in association with TINoor.

\section{FIGURE 10}

The settlement and enclosures of TINoor, the largest concentration of rock art is located at the base of the lower cliff.
To the south, in the Takat pass, there is a large settlement, TAKoo6, high on a plateau protected by two sets of cliffs and number of walls and gates. Unlike the above sites there are clear signs of overlain medieval and later activity (described below), but the basic form of construction is the same - a series of enclosures containing smaller buildings with drystone walls and an open area at the highest point of the hill (this time in the centre).

Radiocarbon samples were taken from occupation layers at depths of 0.4-0.6 $\mathrm{m}$ and provided dates from around the fourth-sixth centuries AD (Fig. 7): TINo15, cal AD 382536; TAMoo1, cal AD 430-615; and TAKoo6, cal AD 411-542, cal AD 423-557. The similarities in layout, architecture and the association with rock art depicting horses strongly implies that TINoo1 was also broadly contemporary with TINo15. although no suitable radiocarbon samples were recoverable. The presence of rotary querns at all of these sites also suggests that despite their remote location (TINoo1 and TINo15 are at least $6 \mathrm{~km}$ from the Draa river, TAKoo6 is located $250 \mathrm{~m}$ above the valley bottom and took 
us two hours to reach on foot), these sites had some involvement with agriculture or agriculturalists. These data support the earlier suggestions of Margat \& Camus (195859: 370) and Jacques-Meunié (1982) that oasis agriculture in southern Morocco predates the Umayyad conquest of the Maghrib and was practiced by autochthonous and sedentary populations.

\section{The Southern Zone of the Middle Draa: LARooz and LARoo6}

Two other early historic hillforts have been examined at Foum Larjam. LARoo6 is a hillfort with similarities to the above group with enclosures, a central alley and a focus at the highest point. At some point it was evidently abandoned for habitation and given over to funerary use. Around 50 distinctive high conical corbel cairns (Type 4) were subsequently constructed all over the top of the hillfort - evidently reusing much stone from the earlier enclosures and buildings, which survive only as vestigial traces. A sample from the lower fill within the burial cist of one of these tombs was dated to cal AD 406-542 and raises the possibility that this site relates to a phase of settlement dating to the early first millennium AD or earlier. Similar reuse of hilltop sites as funerary zones has also been observed in the central and northern zones of the Middle Draa at TISoo8 and TAMoo4.

LARoo2 appears to be of slightly later date with a sequence of dates from organic deposits indicating that it was occupied from at least cal AD 339-534 to cal AD 778 994 (see Fig. 7). The site is a fortified hilltop comprising 50-6o rectilinear buildings (similar to those explored at TINo15 and TAKoo6), mostly constructed directly against the enceinte wall and without the enclosures that characterised the other sites. Access to LARoo2 was via a stepped entrance at the north-west end of the enceinte, with an inner wall funnelling passage southwards once inside. Smaller one- or two-room buildings were focused in the northern half of the site and larger, more complex buildings in the southern half (also the part of the site with the greater numbers of rotary quern fragments). On the slopes and around the base of the site there are many more structures that are probably of contemporary date and a group of c. 15 rectilinear enclosures to the west. these were most likely stock enclosures, rather than gardens, as the Draa river is $1 \mathrm{~km}$ to the east and to the south-east of the site and easily accessible. The site has the highest concentration of rotary quern fragments and grinding stones of any site surveyed so far and is also notable for the presence of a few scraps of imported wheelmade ceramics.
The radiocarbon dates for LARoo2 and the other sites described in this section confirm that these sites date to the mid-first millennium $\mathrm{AD}$ and that there was already substantial settlement in the Draa valley when Muslim armies first entered Morocco. Although the earliest cereal grain (cf. hordeum from LARoo2) recovered thus far dates to the seventh century $\mathrm{AD}$ - a second possible example from TAMoor could not be dated - the numbers of grinding stones and rotary quern fragments are indicative that the occupants were engaged in (or with) oasis cultivation in the Draa valley. There is insufficient evidence of clearance and irrigation close to these sites, but it is highly likely that there was agricultural development in the floodplain of the Draa that was contemporary with these sites.

\section{Medieval 'Towns' and Fortified Centres in the Passes}

As already noted, a key characteristic of the Wadi Draa is the presence of a series of gorges and narrowings along the length of the valley. These have been key locations across time for the control of movement, trade and defence. Particularly striking are a number of large and complex walled towns which were invariably split into a high elevation citadel and a lower-level settlement (either on the slopes or on an accessible shelf) next to the Draa. A combination of glazed ceramics and radiocarbon dates indicate that they date roughly to the tenth-thirteenth centuries $\mathrm{AD}$, the era of the Almoravid and Almohad dynasties in Morocco. These settlements all have prominent enclosing walls, either made from pisé or mortared stone, and the houses are larger and more complex than those of earlier periods.

\section{Zagora (ZAGoor + ZAGoo2)}

The modern town of Zagora sits between the Ternata and Fezwata oasis basins, under the imposing massif of Jabal Zagora which forces the Draa to take a sharp westward bend before continuing on its southward course (Fig. 2). There are two walled medieval sites of Zagora, both situated on this mountain - ZAGoor is the fortress perched on the very summit, with ZAGoo2 constructed on the northern face of the escarpment (Figs 11 and 12). Both sites were exceptionally well preserved until recently and a preliminary plan was drawn from satellite imagery, but inspection on the ground revealed significant recent degradation of these key monuments. The damage to ZAGoo1 is particularly severe due to the systematic demolition of upstanding buildings for their building stone. 


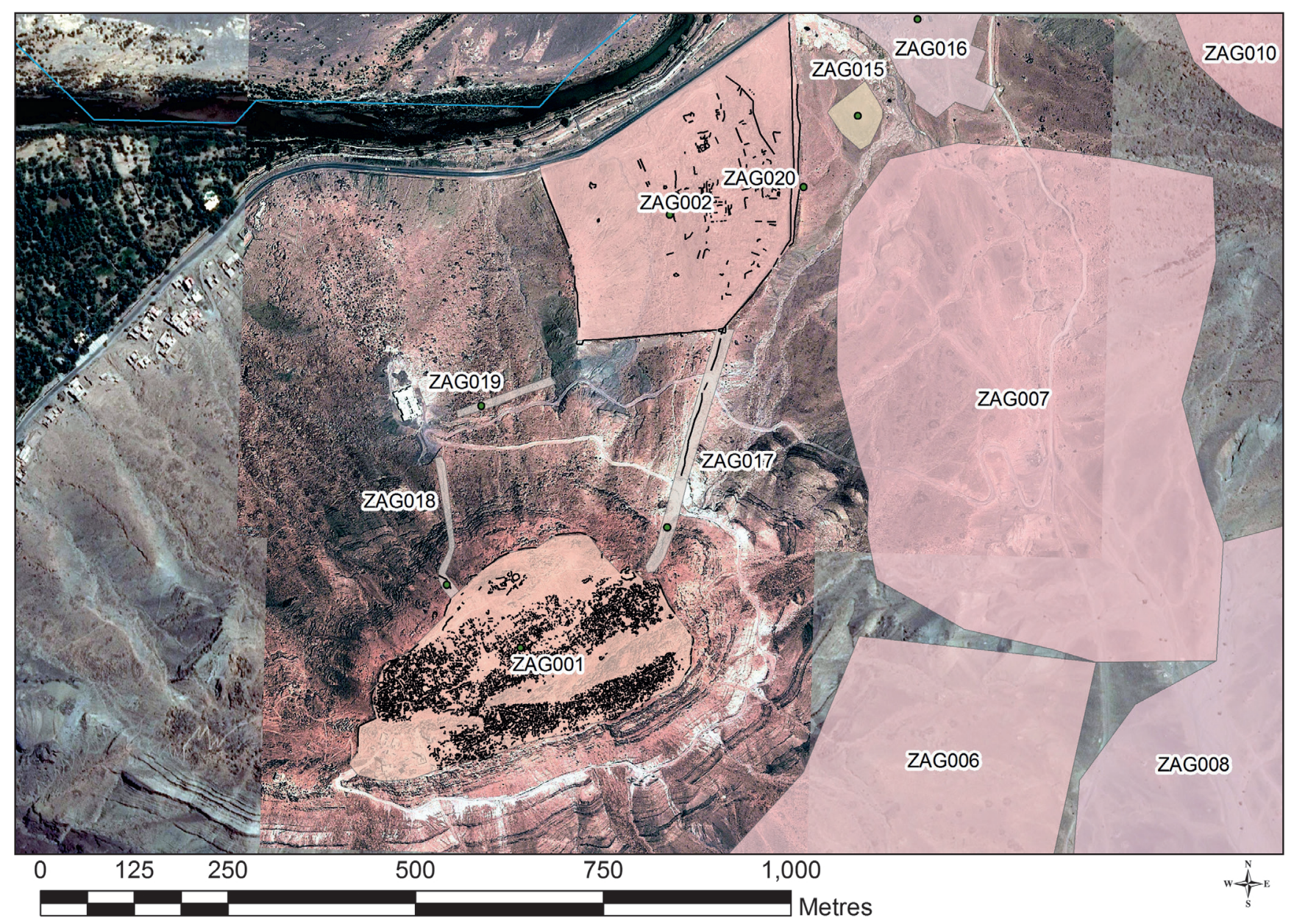

FIGURE 11 Plan derived from satellite mapping of ZAGoor and ZAGoo2 (imagery: Google, DigitalGlobe).

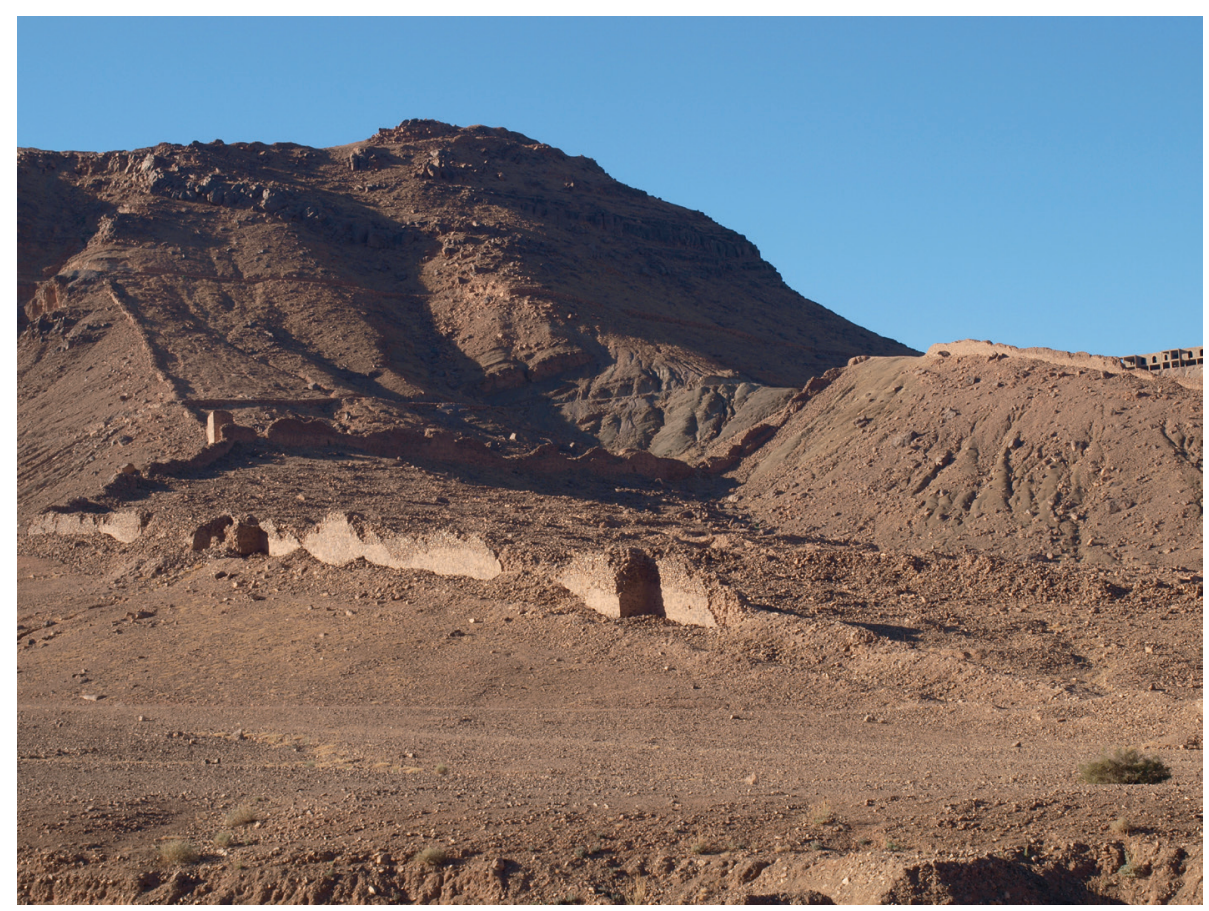

FIGURE 12

ZAGoo2 from the east, ZAGoor sits on the mountain above to the left of the image. 
The sites do not appear to have been exactly contemporary but the fact that the walls of the lower town were connected to the walls of the upper town at some point, suggests that there was at least some overlap of use. Radiocarbon dates from the walls of both the upper and lower town have yielded a set of dates of the eleventh-early twelfth century, consistent with an Almoravid date, but with some evidence of earlier and later occupation in the centuries either side (Fig. 13). Interestingly, the latest dates currently come from the citadel site, which certainly extended well into the Almohad era and possibly later in the thirteenth century. In any event, the traditional association of these sites with the Almoravid and Almohad dynasties looks correct (cf. Meunié \& Allain 1956), though it remains to be seen how far they may have continued under the Merinids (or Wattasids). Among the structures still-standing within the lower town are a series of large tomb monuments, one of which has been dated to cal AD 989-1151.

Another interesting discovery during the season was the identification of pottery kilns in and around an enclosure (ZAG015) just to the east of the town walls of ZAGoo2. These evidently produced the wide range of handmade forms that have been found at the site. No evidence has been noted as yet for the local production of fineware and glazed ware (see pottery section below).

\section{Tidri (LARoo4)}

According to the local manuscript tradition, the site of Tidri was the first Jewish settlement in this part of the Sahara, and dates back to the late antique and medieval period though different traditions give an even earlier foundation date (Jacques-Meunié 1982: 178-88). Its location is strategic in that it dominates the narrow pass through Jabal Beni Selmane, south of which the Draa makes its decisive turn to flow towards the west - in other words, Tidri sits at the apex of the 'coude du Draa'. The settlement here comprises several discreet elements. Irhir $\mathrm{n}$ Tidri is a fortified hilltop settlement (LARoo4) overlooking two passes from the Ktawa to the Mhamid basins (Figs 14 and 15). It was defended on its western flank by a wall with at least six square towers faced with slabs and containing a very hard pisé core ( $4 \mathrm{~m}$ thick). Access to the upper site was gained via a monumental dogleg gateway on the south-west corner marked by two large square towers. A second access point was located to the east via a narrow gateway that led down a steep slope to a lower area of the site (LAR025) and eventually to the wadi floor. This path and LAR025 was protected by a further linear stone-faced pisé wall (dated to cal AD 1046-1221 - see Fig. 12) with at least seven towers projecting on its southern side.
The upper settlement was divided into a series of compounds leading off a central street, each consisting of rectangular rooms of different sizes. The largest compounds are located in the west sector of the site and there is a central building with a very large courtyard which may be significant. There are at least two phases of occupation, the second visible in repairs and later huts on the southern side of the site. Below and to the south of the defended site (LARoo4/025) were a further two small settlements comprising of c. 45 scattered single-room and multi-room drystone structures (LARoo3 and LARo13). A test-trench demonstrated that the structures of LARoo3 served as dwellings, though other uses cannot be excluded and a sample from occupation material indicate a roughly contemporary date of cal AD 1166-1263. So far then, the dating evidence from Tidri suggests a fortified site and some associated habitation of Almoravid date. We do not yet have evidence to confirm the late antique tradition - unless it relates to the nearby LARoo2 hillfort or one of a number of other still uninvestigated sites in the immediate area. The supposed Jewish associations of any of the sites close to Tidri have also not been demonstrated.

\section{Imi $n$ Takat $n$ Draa (TAK Area)}

In the pass between the Fezwata (Tamegroute) and Ktawa basins of the Wadi Draa is a dense complex of fortified settlements and associated features (Fig. 16). The pass of Imi n Takat is a relatively narrow defile, with the river in its centre and numerous fortified sites on either bank and, on the east side, extending far up the impregnable looking scarps of Jabal Beni (Jacques-Meunié 1982: 141-144 for several mentions of the pass as separating the Fezwata and Ktawa oasis areas, but no references to the sites controlling this key passage obligé). The earliest of these is a walled hilltop site TAKoo6, described above. This site clearly had more than one phase of development. The plateau retained its importance into the medieval period with a group of three walls across the spur to the north. This group (TAKoog) consists of a large 3-4 m wide drystone slab wall, a seven course pisé wall with stone slab mortared pillars, and finally a stone slab (mortared) wall. On the south-west tip there is a small mosque ( 4.5 by $5 \mathrm{~m}$ ) with a mihrāb facing southsouth-east as is common for early mosques in southern Morocco (Bonine 1990). Furthermore, the ceramics from across the site suggest multiple phases and include both wheelmade and painted examples.

Of certain medieval date, TAKoo4 is an urban-scale settlement running for c. $0.5 \mathrm{~km}$ along the east side of the pass below TAKoo6. It was constructed on the lower slope, with defensive stone walls ( $1.5 \mathrm{~m}$ wide) demarcating 


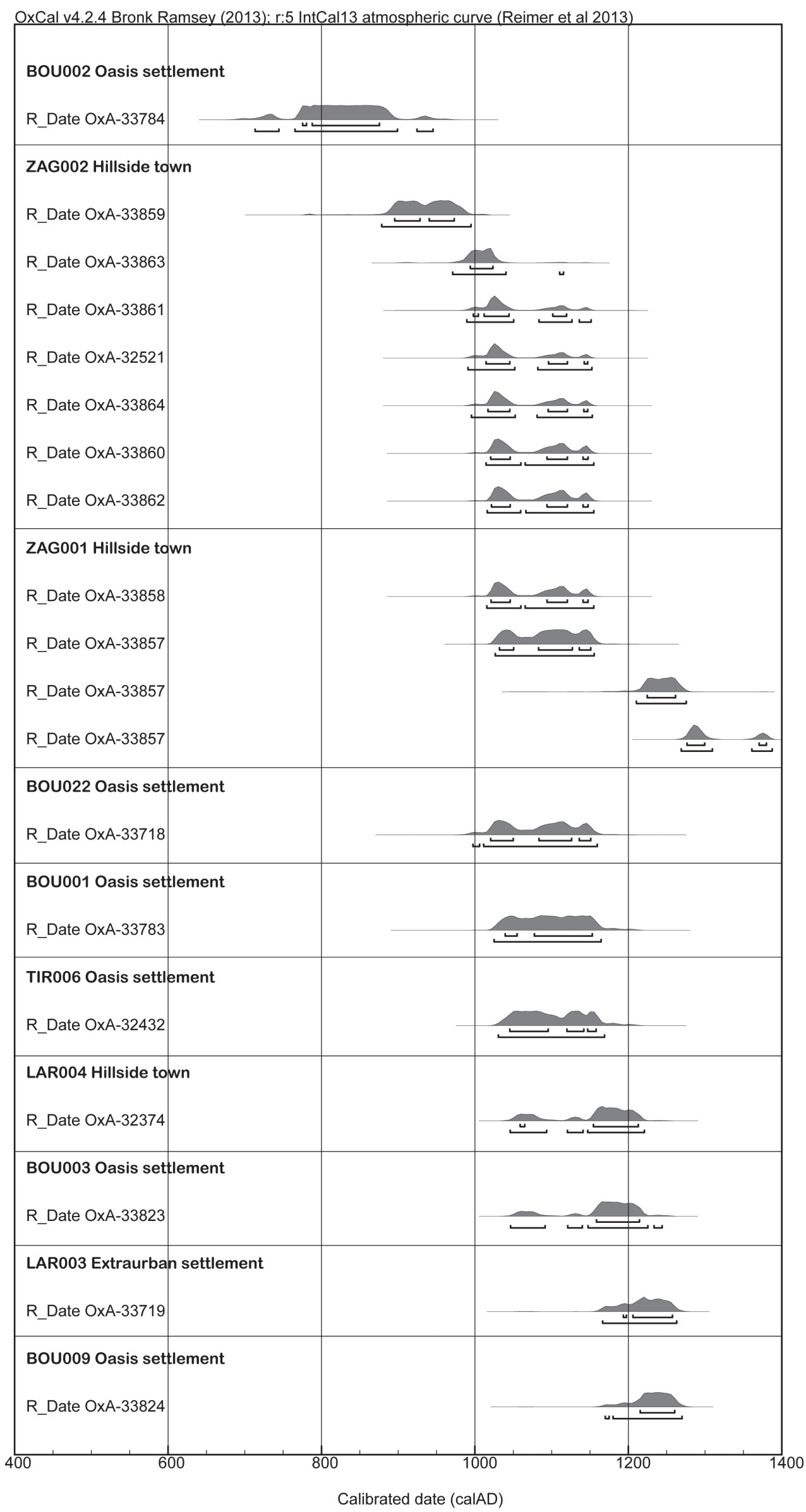

FIGURE 13

Radiocarbon dates from medieval sites. 


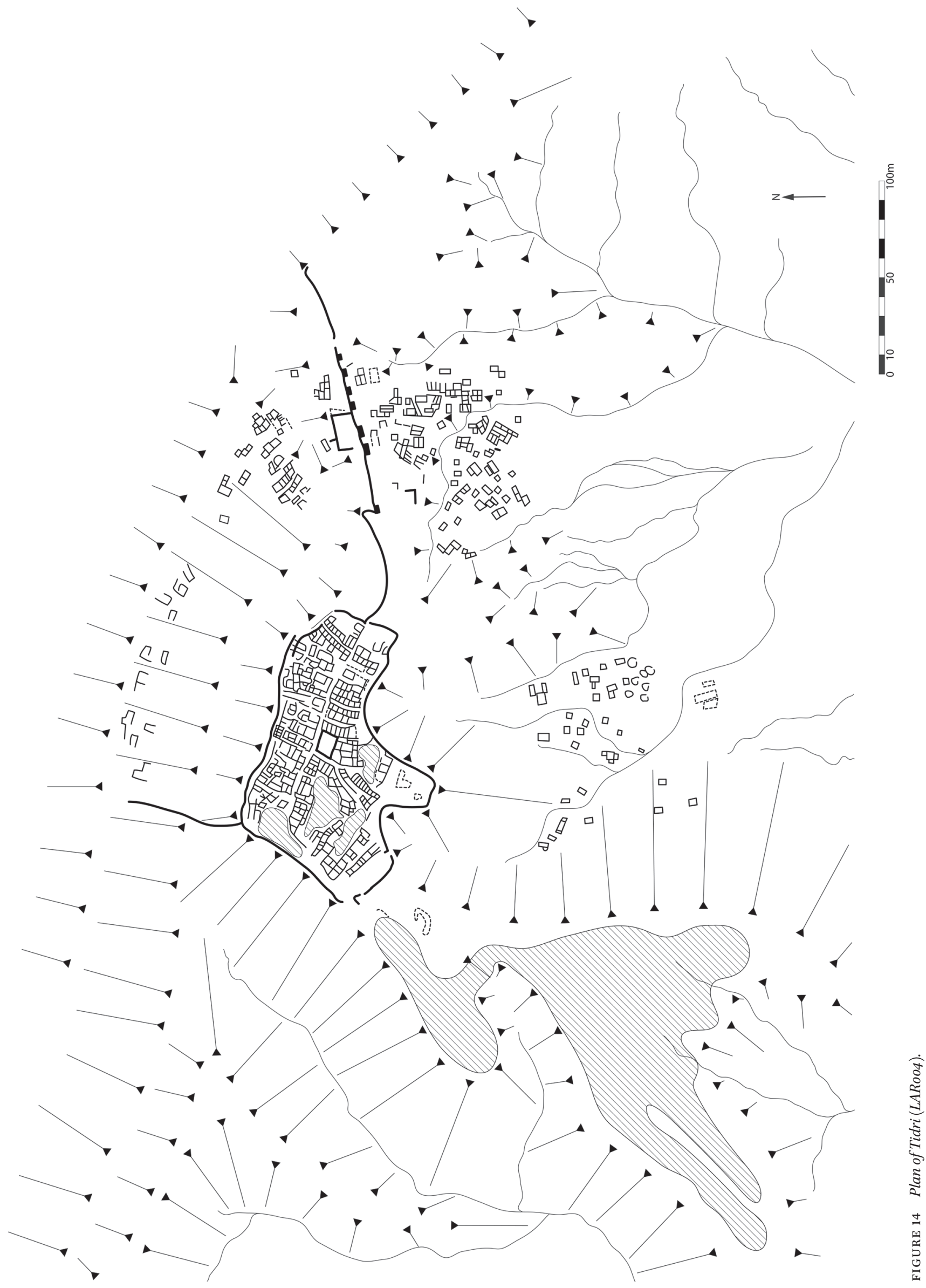

JOURNAL OF AFRICAN ARCHAEOLOGY 15 (2017) 141-172 


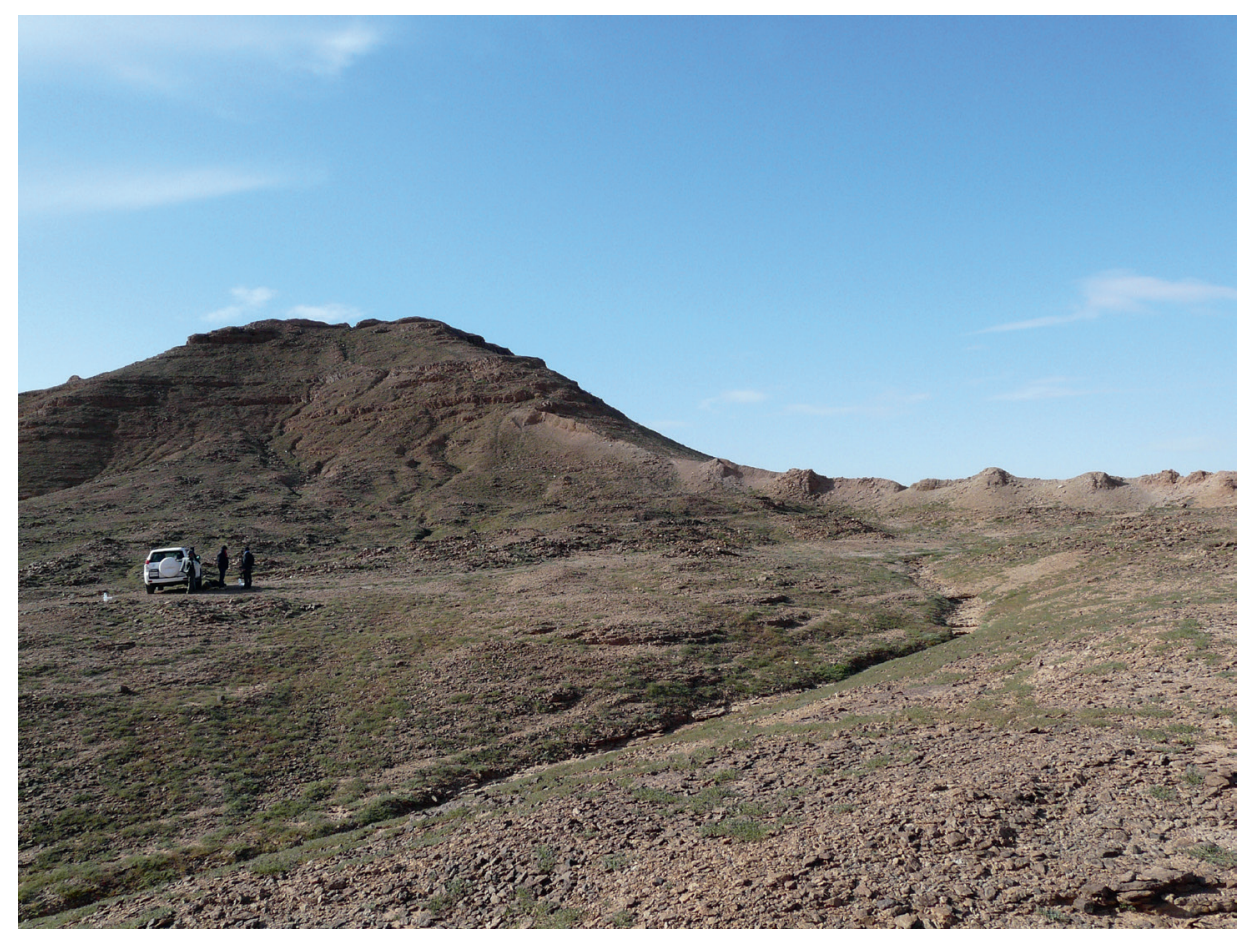

FIGURE 15

The pisé wall of LARoo4 from the southeast, LARooz is at the base of the hill on the left of the image.

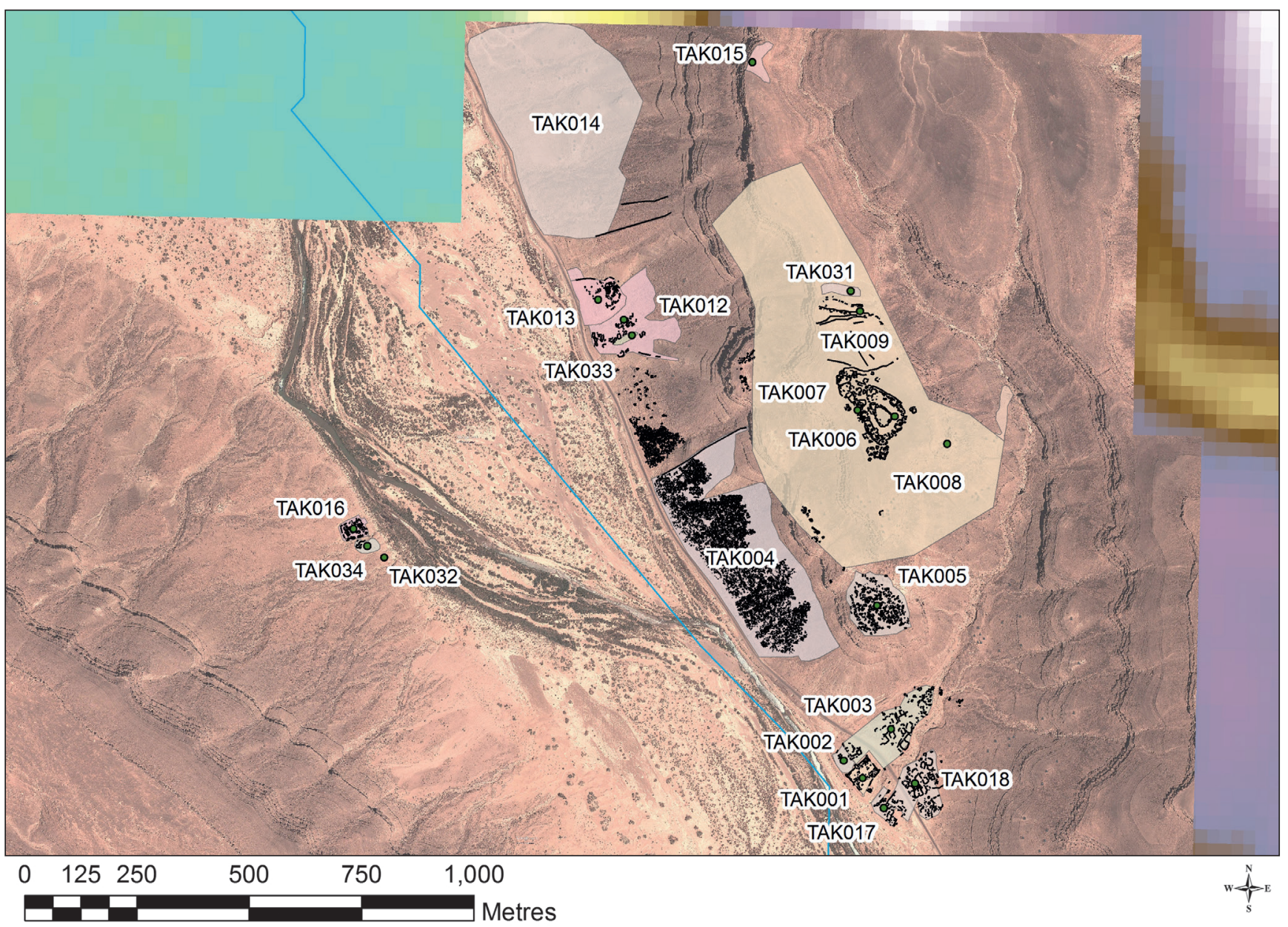

FIGURE 16 Plan derived from satellite imagery of sites around the pass of Imi n Takat n Draa (TAK) (imagery: Google, DigitalGlobe). 
the north and south ends of the settlement, the cliff-like escarpment on the east side and a now vanished wall on the river side, almost certainly lost in modern road construction here. The interior of the site comprises over 500 rectilinear structures and over 50 later sub-circular buildings, which were frequently built against the earlier structures. A network of streets is also visible in some areas, such as in the northern part of the site where a stretch of c. $100 \mathrm{~m}$ with several smaller branches could be identified. Unfortunately our only dating sample from TAKoo4 proved to be of intrusive modern origin, though the limited pottery recovered is consistent with a medieval date.

TAKoo4 seems to be closely related to, and contemporary with, a smaller and unwalled settlement, TAKoo5, which is located on an intermediate terrace of the hill between TAKoo4 and TAKoo6. There is, however, no discernible route connecting TAKo04 and TAKo05, which are separated by the near-vertical cliff face of Jabal Beni. A terraced field system/enclosures of unknown date, again bordered by a large drystone boundary wall, are found to

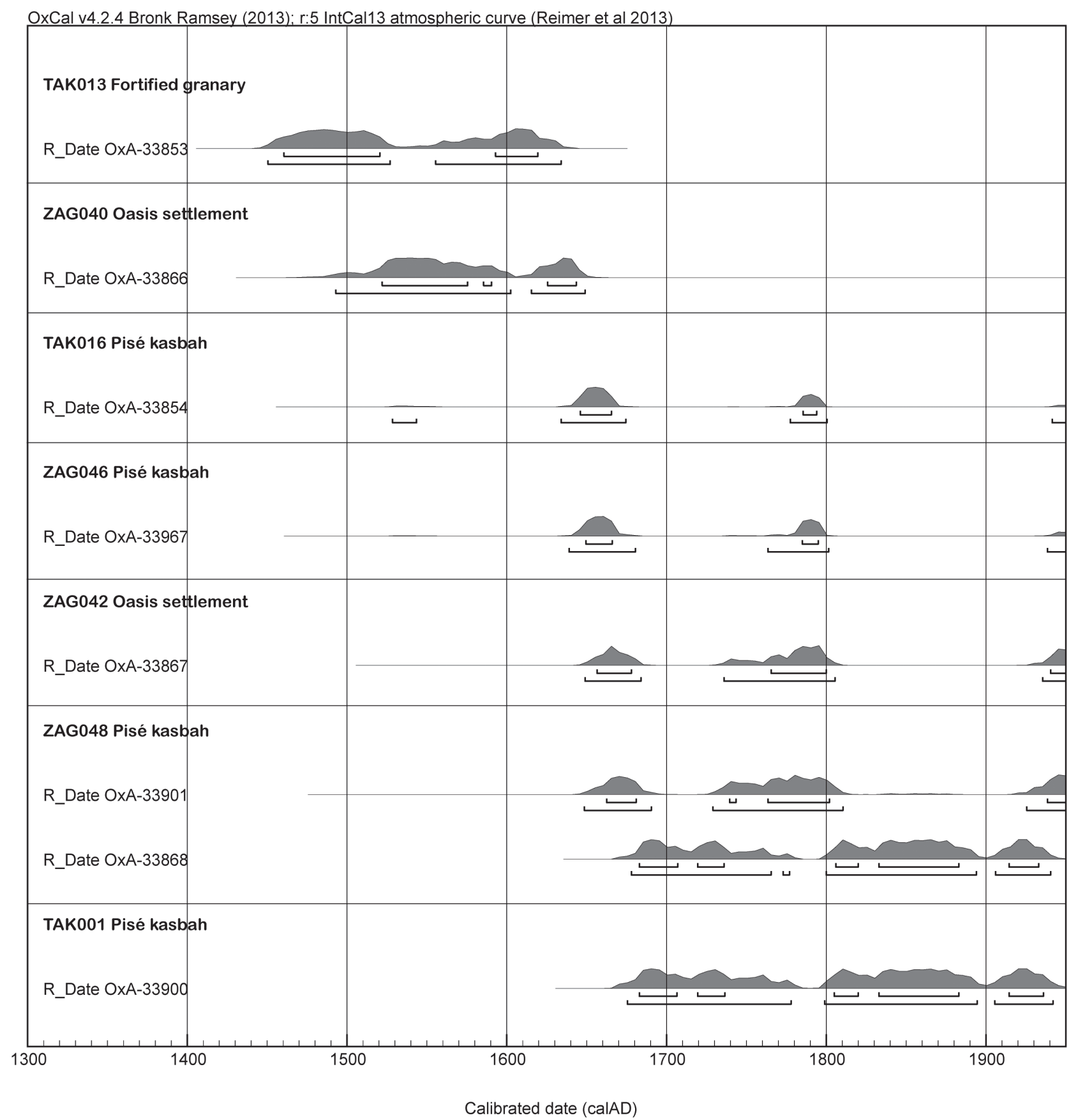

FIGURE 17 Radiocarbon dates from post-medieval sites. 


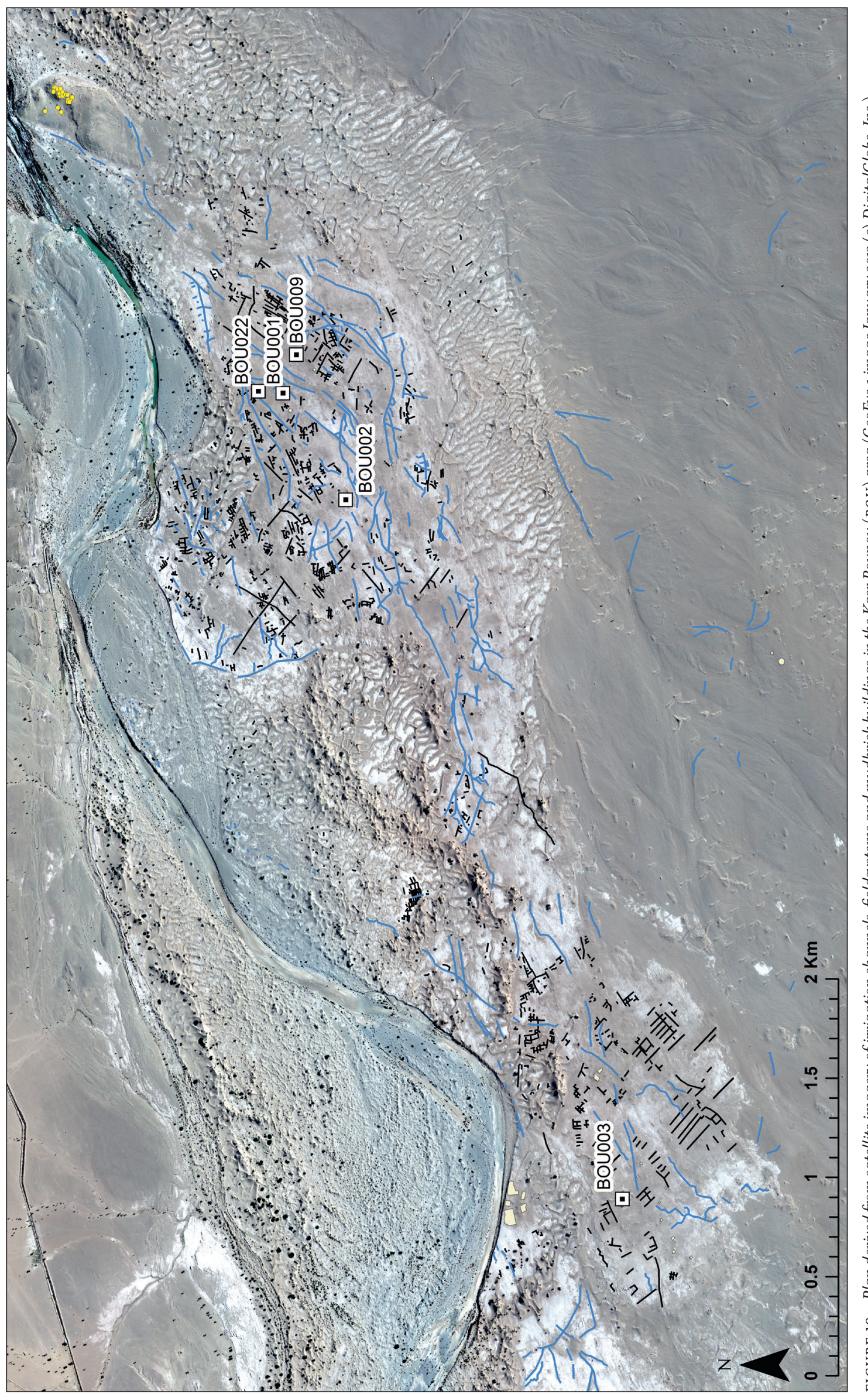


the north of TAKoo4 with a series of later rectilinear buildings built on their foundations (TAKo33).

Several other smaller stone-built fortified sites have also been examined and dated (Fig. 17, including: a fortified communal granary (TAKo13 - cal AD 1450-1634) to the north of TAKoo4; a qasr (TAKo16 - cal AD 1528-1950, this is certainly of pre-180o date and has no evidence of the more obviously post-medieval ceramics) on the west bank of the Draa, opposite TAKoo4; there is also a classic pisé kasbah (TAKoo1 - cal AD 1675-1950) in the foot of the pass immediately south of TAKoo4.

\section{Oasis Settlement, Agriculture and Water Management}

The archaeology of the oasis is another key theme of our research, though for large parts of the Wadi Draa valley, the thriving modern oasis and its active irrigation canals and water distribution systems effectively mask the earlier phases of development. In seeking to investigate earlier settlement, organisation of land and irrigation works and so on, we have focused on a few locations in the valley where the oasis has been abandoned before the early modern age and the distinctive pisé fortified villages ( kasbahs) of that period are absent.

\section{Kasr Bounou Area (воU)}

To the east of Mhamid, the oasis has been partially overwhelmed by sand dunes and has been abandoned. From the satellite imagery we identified an area on the south terrace of the Draa that was relatively open and where extensive traces of past settlements, gardens and irrigation canals and smaller distribution channels were plainly visible (Fig. 18). The main visible settlements here are fortified sites (qsur) built in mudbrick (Fig. 19). These appear from the associated pottery to be medieval. The radiocarbon dates now available suggest that the earliest qasr may have been built as early as the eighth century AD (BOUno2 cal AD 713-945) and, overall, the oasis landscape appears to have been well established by the eleventh or twelfth centuries AD (as shown by the dates from BOUoo1 - cal AD 1025-1164, BOUoo3 - cal AD 1046-1245, BOUoo9 - cal AD 1170-1270 and BOUoo22 - cal AD 997-1159, see Fig. 12). A second, similar region near Kasr Tiraf was briefly visited and one of the qsur was radiocarbon dated to the same period (TIRoo6 - cal AD 1030-1169). The date of abandonment of this area of the oasis is uncertain, but there is no evidence of later medieval activity and descriptions of the valley from the sixteenth century describe the area as uninhabited and the former capital of Tesuf in ruins (Mármol Carvajal 1573). The indications from the nearby Foum Larjam area at LARoo2 strongly suggest that there may also be earlier origins to the oasis farming in this area. At the moment, however, there is no direct evidence that it developed on the south terrace of the Draa before the eighth or ninth century AD.

Several major canal systems flow through the former oasis from the north. As part of this preliminary survey, we

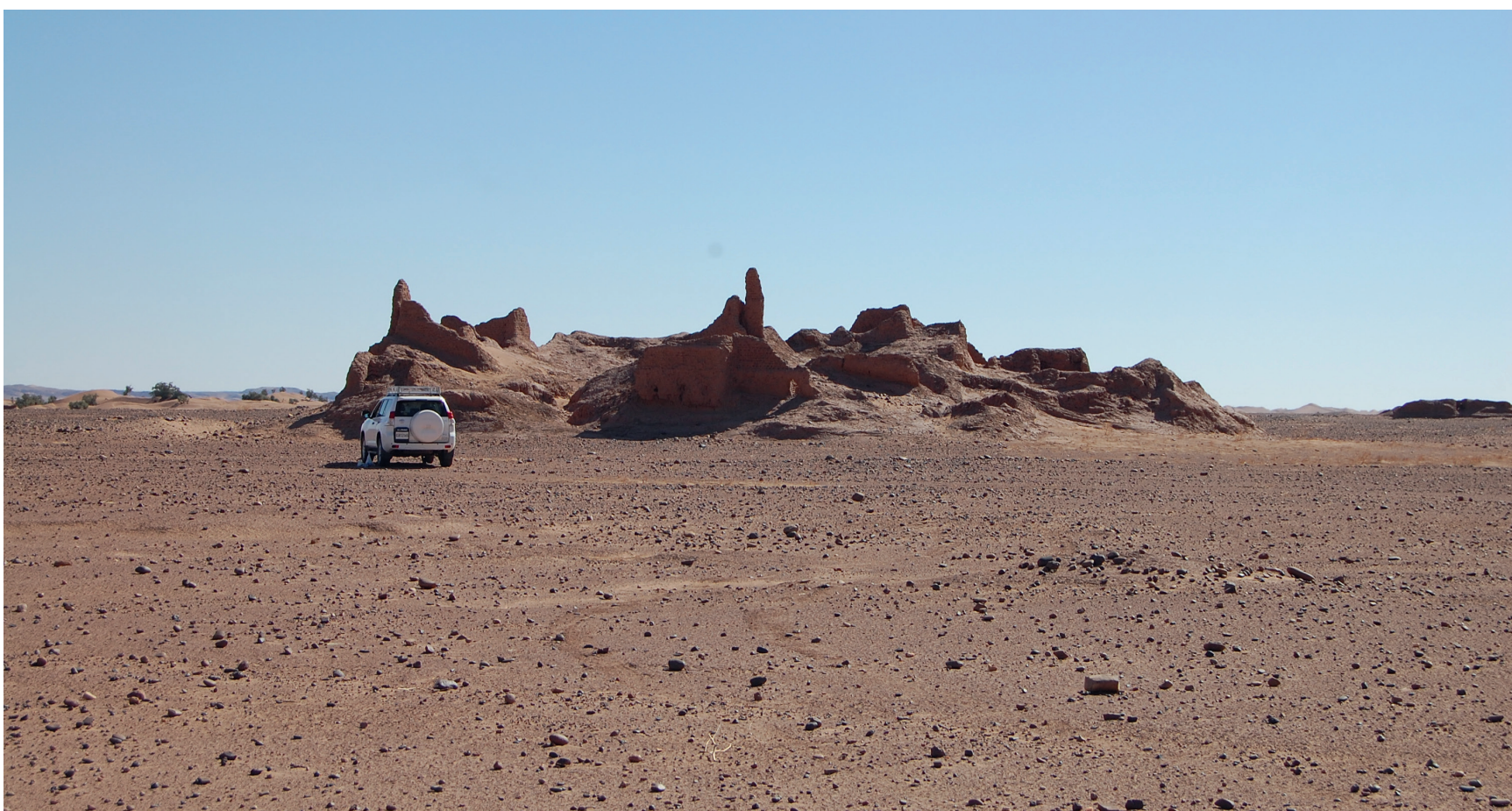

FIGURE 19 The mudbrick fortified site of BOUoor. 
mapped the canals from satellite imagery and excavated sections in part of the main canal (BOUno1o) and an associated offtake/field lateral. The main canal of BOUno delivered water to an extensive network of gardens (BOUoo4), where the main canals split into sub-main and smaller field lateral channels. These supplied water to a layout of small fields/gardens which are also apparent in the satellite imagery, possibly even when water levels around Mhamid were depleted. Water flow into separate canals/ laterals may have been controlled by the expedient of removing/re-building earth bunds so that water could flood into each small plot; no remains of obvious sluice-like devices were identified.

Traces of similar relict canals and a foggara (underground water channels similar to the Persian qanat, see Wilson \& Mattingly in Mattingly 2003) are apparent south of the TAK pass, and probably represent a stage of irrigation which predates the modern water management schemes constructed since the 1970s. There are also a few traces of canals and foggaras in the Zagora area which can be mapped from satellite imagery, although many more are likely to have been removed by subsequent phases of cultivation and irrigation which are necessarily focused in the same best-watered areas in the valley bottom.

\section{Finds}

\section{Pottery}

The pottery analysis aimed to build up a basic chronological framework into which to fit the sites investigated. No previous pottery research is reported from the Draa region, thus the only available comparative data are from Sijilmasa and from sites in northern Morocco or closer to the Atlantic coast (see in particular Cressier \& Fentress 2010). Four broad pottery phases, supported by radiocarbon dates, were identified and sites relating mainly to one of these phases were prioritised for study in detail: fourth to sixth centuries AD, TINo15; seventh to tenth centuries $\mathrm{AD}$, LARoo2; tenth to thirteenth centuries AD, ZAGoo1; seventeenth to nineteenth centuries AD, ZAGo48. Most sherds were recovered from surface collections, with very few found in test pits. Intermixing of more than one chronological phase was thus expected, although not always detected. A continuum in the technologies of handmade pottery manufacturing has been identified. We do, however, have gaps in our sequence due to a lack of suitable sites, particularly prior to the fourth century AD and between the fourteenth and sixteenth centuries.

At TINo15 the pottery collected consisted mainly of medium-size cooking pots with lateral grips or a cord- shaped application (cordon) on the upper part of the body or very close to the rim band (Fig. 20a). Most of the examples are in high relief and are decorated with spaced finger impressions creating alternate knobs. In a few cases the corded application is less high relief and so are the impressions/knobs. Some bowls or open forms are reported as well (Fig. 21a-l). Fabrics are all coarse with mediumto-large minerals inclusions, sub-rounded-to-flattish in shape, in a medium-to-high percentage in the paste. No detailed analysis has been done yet, but those mineral inclusions appear to be shale/mudstone, sandstone and basalt. The local geology suggests sources of raw materials were local. Although many of the sherds recorded are small and abraded on the surface, the pinching technique predominated in the shaping process. However, it is not clear which other techniques were used in combination with pinching. Surfaces seem mainly to have been finished by smoothing or self-slipping, but again the state of preservation of most of them does not allow further description. However, it can be stated that that vessels were quite roughly shaped and finished.

The pottery assemblage from LARoo2 strongly resembled the aforementioned one (indeed part of it is probably contemporary with TINo15), with the addition of closed forms, mainly painted jars with handles, which had the same coarse mineral-tempered fabric of the local productions (see Fig. 21p). A few wheel-made fine ware products were also recovered and may be among the earliest imports in the region. Fabrics were untempered and pink-to-light brown in colour; surfaces were smoothed or glazed. At ZAGoor cooking pots with corded application and impressed decorations were still produced, this time also with a very thick and large variant (similar to Fig. 21n-o). A trend towards simplification of the applied cordon decoration is visible, meaning that at this point most of them were almost flat with fingernail impressions (Fig. 21f-i). Fabrics were again coarse and mineral tempered. Fine ware (Fig. 21q-s) and glazed wares (Fig. 21t) were now quite common, but rarely in the majority at a given site. Some of them were made with a very fine, untempered, clay incorporating tiny coloured mineral inclusions similar to those encountered in the fabrics of the hand-made wares, suggesting by then a local production of part of the fine and glazed vessels and the introduction of the wheel-made technology in the region. It is interesting to note the production of some more refined bowls or pots, which at first sight look like wheel-made imports, but on closer inspection reveal a fine-to-medium-coarse fabric with rock inclusions of the local tradition (Fig. 2oc; Fig. 21h-j). These vessels, usually hand-made are typically decorated with a horizontal band of incised 

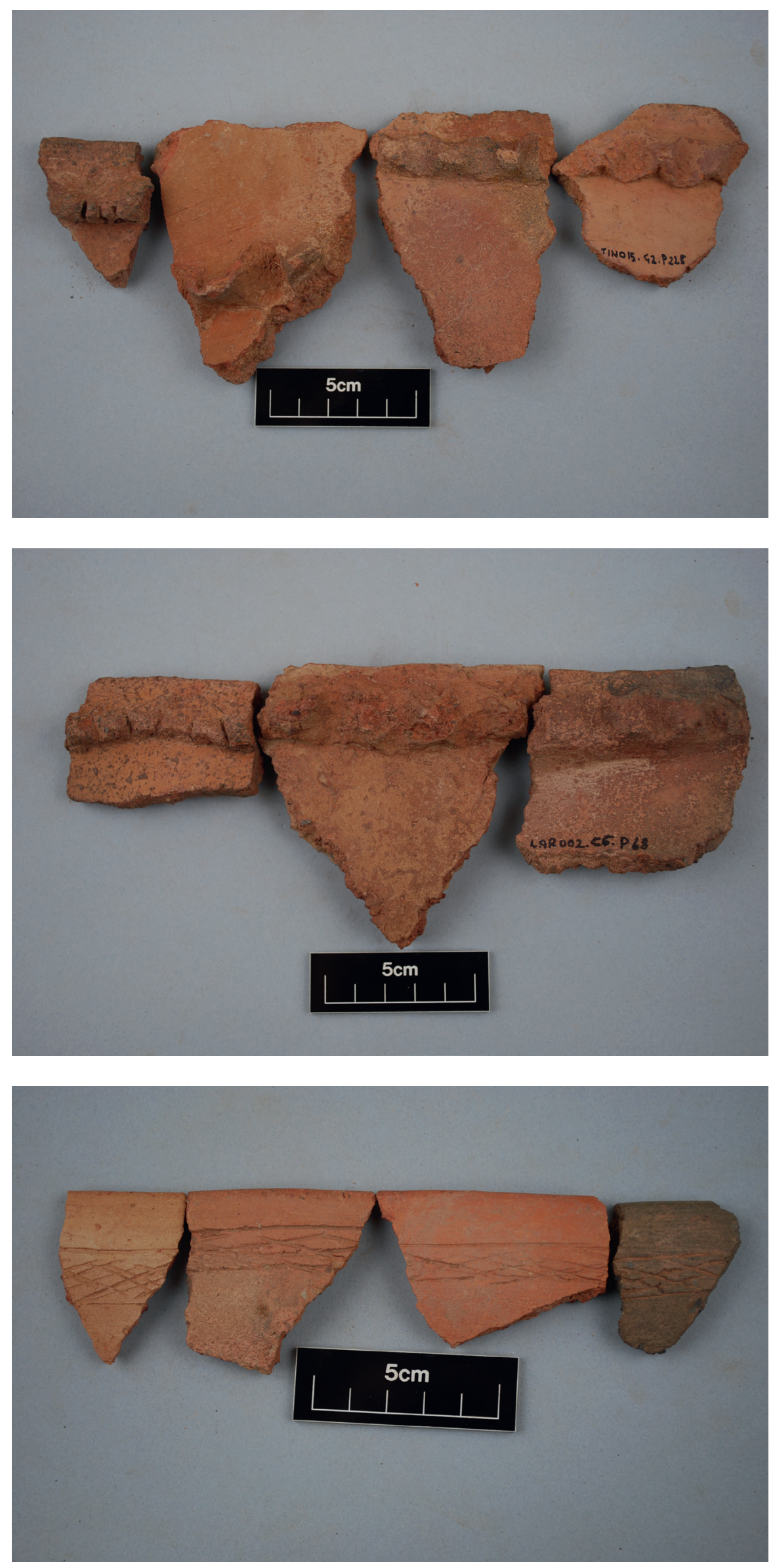

FIGURE 20

Examples of decorated forms: a) cordoned decoration (TINo15) b) cordoned decoration (LARoon) and c) incised decoration (BOU area). 

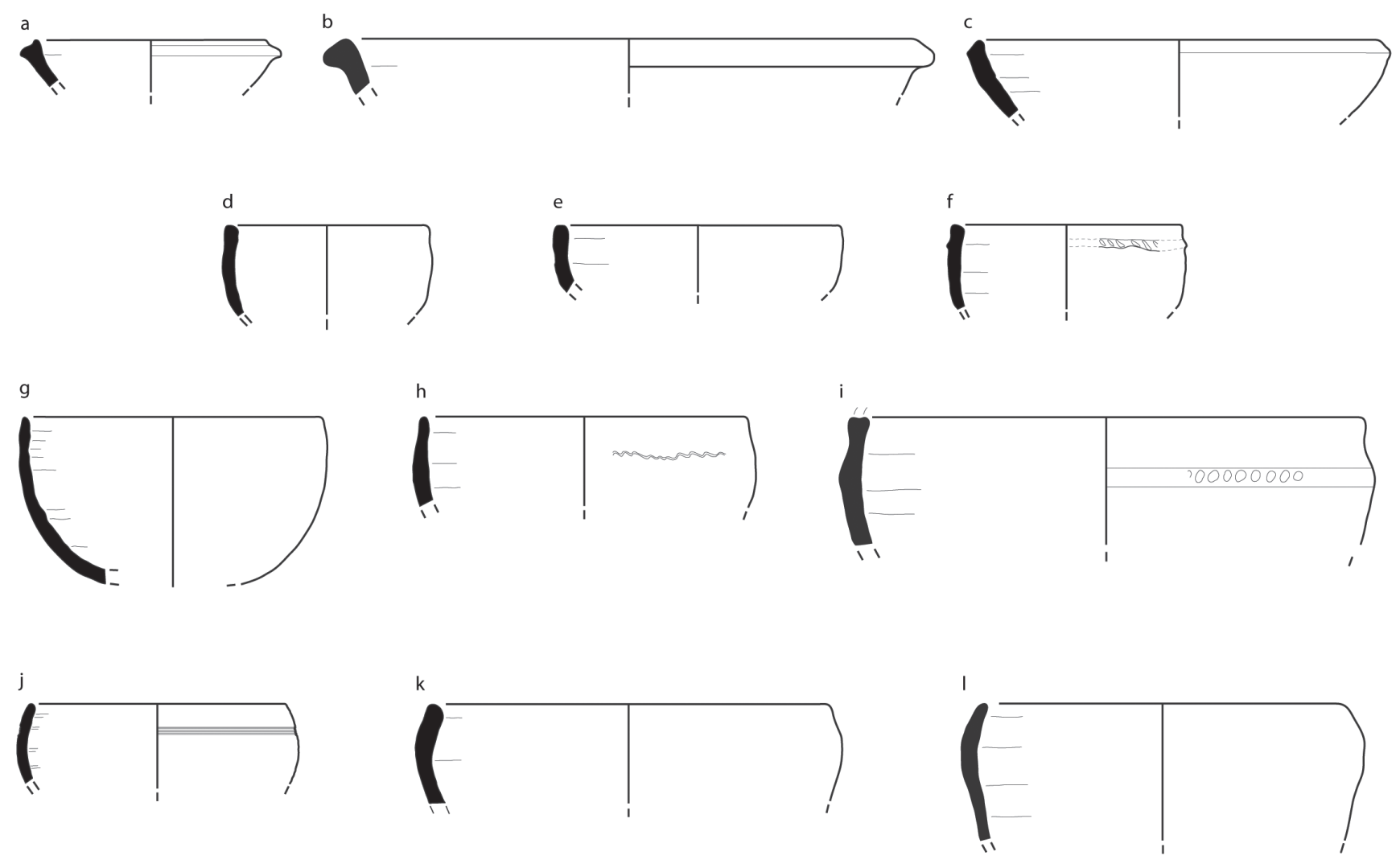

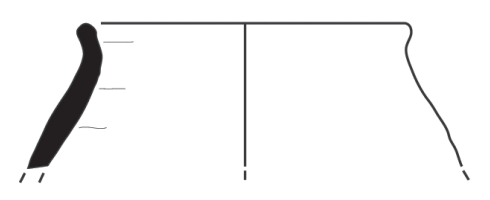

$\mathrm{n}$

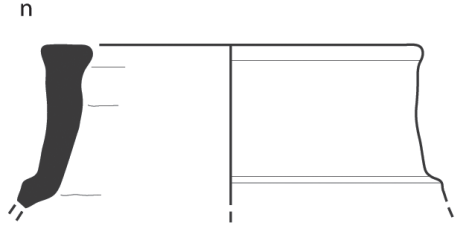

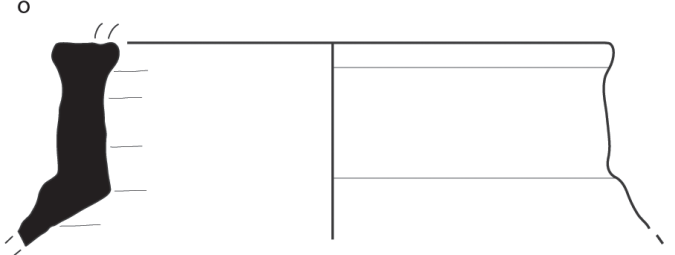

$\mathrm{p}$
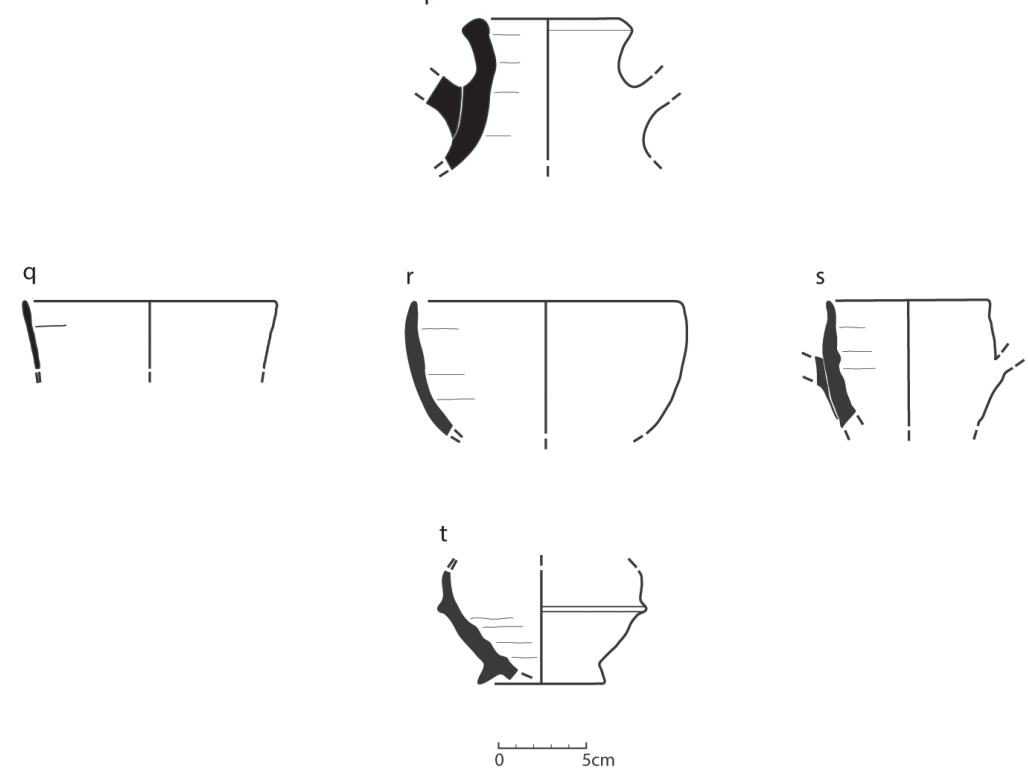

FIGURE 21 Examples of hand-made (a-p) and wheel-made ( $q$ - $t)$ vessels from ZAGoor: $a-l$, bowls; $m$-o, collared pots; $p$, jar. 
criss-cross pattern (Fig. 20c). The most recent pottery from site ZAGo48 still has traditional pots with grips or corded applications as well the more simplified variants. Fine ware and glazed productions with modern-day forms are more common and for the most part locally made.

The structured survey collections of $10 \mathrm{~m}^{2}$ provide an insight into the basic characteristics of ceramic assemblages from the Wadi Draa. A total of 143 circle collections located by GPS were made, with at one extreme 16 containing no ceramics and at the other, an example from BOUoo2 containing 488 sherds $(5.04 \mathrm{~kg})$. The numbers of handmade, wheelmade and a total count were recorded for each collection allowing comparison between different site types. Ceramic density was lowest on the early historic hilltop settlements ( 0.5 sherds $\left./ \mathrm{m}^{2}\right)$ which commonly would have several areas with no ceramics. The three sherds of wheelmade ceramics can be attributed to LARoo2 and TAKoo6 which both have evidence of some medieval activity. Ceramics are more densely spread over medieval hilltop settlements $\left(1.4\right.$ sherds $\left./ \mathrm{m}^{2}\right)$ with wheelmade ceramics accounting for 14 per cent of collections. The same ceramic density is found on early modern sites, but wheelmade ceramics account for 29 per cent of collections. The oasis areas of BOU and ZAG present a contrasting picture with 15.8 sherds $/ \mathrm{m}^{2}, 6$ per cent wheelmade and 0.6 sherds $/ \mathrm{m}^{2}, 41$ per cent wheelmade respectively. There are several factors that can be identified. Firstly, the deflated surfaces of the воU area have created ideal conditions for preserving ceramics whereas the still cultivated oasis areas of ZAG reduce visibility and are likely to have been particularly harsh on handmade pottery (hence the overrepresentation of wheelmade ceramics). The hilltops produce a more consistent picture and it is clear that the earliest sites have very little pottery (inhibiting our ability to characterise them) while the more recent in date the higher the percentage of wheelmade pottery. It is difficult with these data to compare regions with sites of similar date and type, but the Zagora complex (ZAGoo1/ZAGoo2) stands out from other medieval settlements with a higher density $\left(2.4\right.$ sherds $\left./ \mathrm{m}^{2}\right)$ and more imports (18 per cent).

\section{Metal and Metalworking}

The survey has produced evidence for the use of metal at oasis sites (BOU area, TIRoo5), hilltop sites (LARoo2, TAKoo6, TAMoo1), an urban site (ZAGoo2) and a tumulus burial (ZAGo54). The vast majority of the metal recovered was copper-base metal, but three indistinct fragments of iron (perhaps nails) were also found. There are known copper sources quite close to the Draa valley (Rosenberger 1970; Mouttaqi et al. 2011) and copper working may have been an important adjunct to oasis farming and commerce. Evidence for what was probably small scale metalworking in the form of ore and slag was found in the воч area, at LARoo2 and TAMoo1, but at this stage no metalworking installations (hearth, furnaces, smithies), or mining areas have been recognized.

\section{Beads}

The survey has produced a large amount of evidence for ostrich-shell beads and a small number of stone beads/ amulets (the latter also found in graves). A concentration of ostrich bead making activity was noted in the во $\mathrm{U}$ area, though it is not clear if it relates to the medieval oasis or to earlier activity (or both). All stages of production were attested. Tool marks on the beads indicate the use of stone tools to knap them into a shape, and to produce the circular hole in the centre. Pointed lithics that could have been used for this task were also found at BOUoo8. The evidence so far suggests that the BOU area was a centre for this sort of bead production. Evidence for bead-making was much lower elsewhere in the Wadi Draa.

\section{Lithic and Stone Finds}

Compared to ceramics, stone artefacts recovered were fewer in number. Early Palaeolithic tools, together with a Middle Palaeolithic Aterian point were collected at TMGoo2 in the valley bottom; Middle Palaeolithic evidence was also found scattered throughout the concession area. A small sample of blades and debitage, possibly Neolithic in date, were found in the BOU and LAR areas. Fresh looking debitage from ZAGo21 and surrounding sites also attests flint knapping in the medieval/modern period.

Two clusters of unusual stone objects, collected in two different locales in the воU area, merit further description. BOU 21 consists of 16 pebbles of different sizes. One large pebble was naturally shaped; three were small to medium size flat pebbles knapped on both sides of the same extremity to leave a peduncle in between; six were flattish flakes from larger flat pebbles, again knapped to obtain an axe-like shape (all but one had cortex on one side). Four flakes, one with cortex, were broken horizontally on the top and then notched; two were thicker flakes more irregular in shape. The second cluster at BOUo18, consisting of 19 objects, was similar to the above, with eight very roughly made axe-shaped stones. Four objects resembled knifes, as they were notched only on one side. Although found on the surface in a medieval context, both sets of lithic objects share similarities with objects found elsewhere in North Africa and datings from the fifth millennium BC 


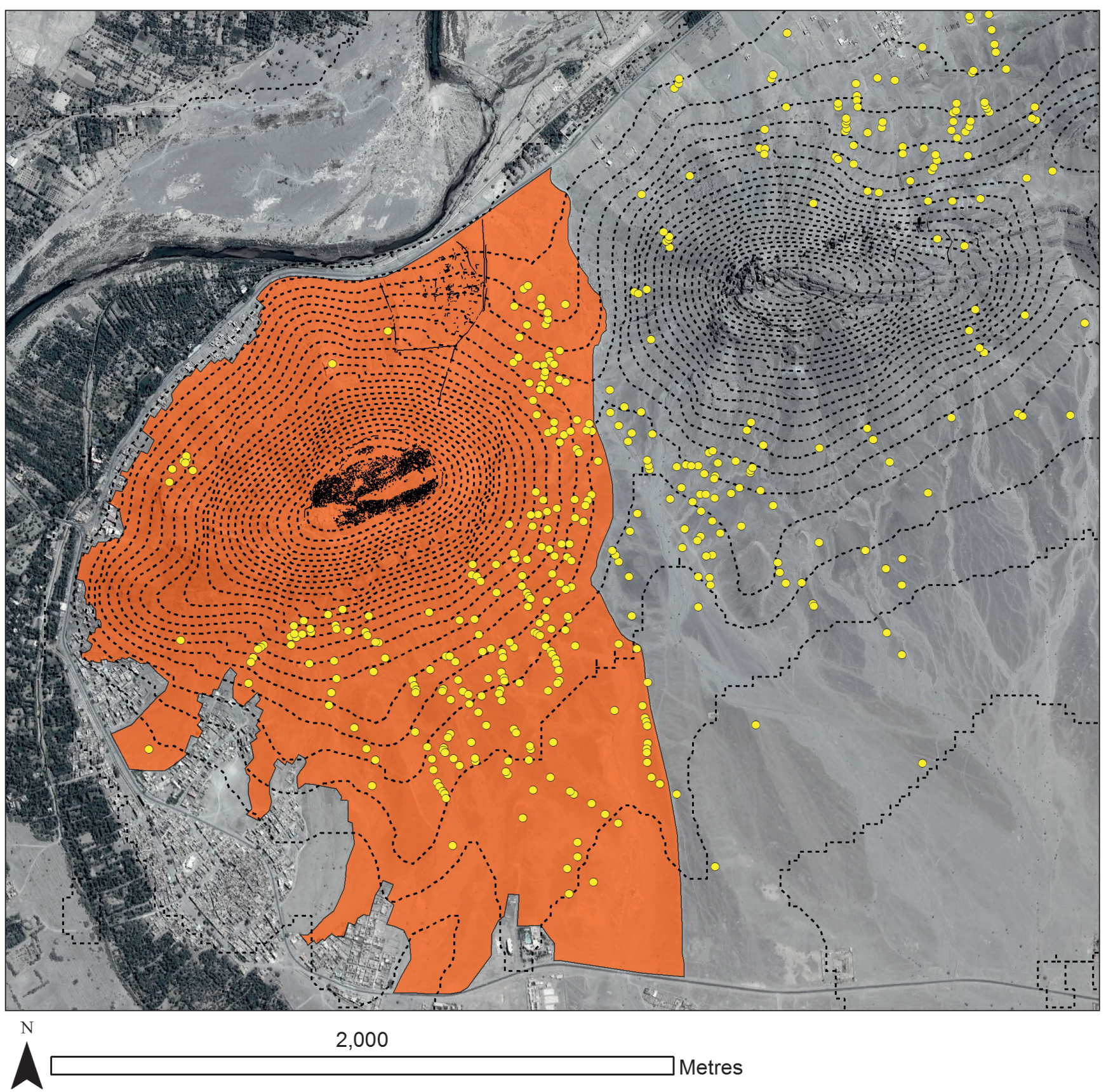

FIGURE 22 Proposed protected zone around the medieval town of Zagora (ZAGoor/ZAGoo2) (imagery: Google, DigitalGlobe).

to modern eras, making their chronological attribution very difficult (di Lernia et al. 2013). The function of these objects remains unclear, as they lack an effective cutting edge and some are too small to have functioned as tools. They may have been produced for ritualistic purposes.

Several sites in the BOU, LAR, TIN and ZAR areas produced stone grinders and saddle querns. With the exception of a basalt saddle quern from ZAGooz, all of these tools appear to have been composed of local rock, either from river beds or cliff sides. Apart from a saddle quern from BOUoo1, it does not appear that these objects were significantly modified from their natural form. The rounded river pebbles seem to have been routinely collected for use as grinders and pounders. The remaining stone artefacts recovered consist of spindle whorls (from LARo15 and TINo15) and a possible lamp from BOUooz. Also spindle whorls made of ceramic were found at BOUno 4 and TINo15. The material of composition is the only difference between these objects, which are otherwise of similar weight and size. 


\section{Conclusion}

The Middle Draa Project has already demonstrated the richness of the archaeological heritage of the valley. Sites have been surveyed from all the key areas of the Middle Draa, from the Agdz area to south of Foum Larjam. We have targeted different settlement types, ranging from the large urban centres, to smaller oasis villages, to hilltop sites on the periphery of the oasis, to pastoral encampments. We have started to catalogue the impressive evidence of funerary archaeology for both the pre-Islamic and medieval eras and have made some significant additions to the knowledge of rock art in the region, in particular demonstrating an association between the horse imagery and two hilltop settlements in the Tinzouline area. The survey has also yielded evidence of more remote prehistoric periods of activity, though our focus on sites with standing remains identified in the satellite image analysis means that these earlier periods have not yet been systematically explored.

The fieldwork has made a number of major discoveries that should change our picture of southern Morocco. Chief among these is the presence of major hilltop settlements that date to the late antique period, some of which may have been associated with oasis cultivators - though this economic orientation needs further excavation and sampling work to verify. The AMs dating programme has proved an effective way to demonstrate the chronological sequence of the sites recorded. This also adds to the growing corpus of dates from proto-historica and historic structures across the Sahara which are transforming our understanding of oasis settlement and agriculture (see for example, Mattingly 2007; 2010; 2013; Sterry et al. 2012; Sterry \& Mattingly 2013).

The creation of secure typologies of pottery and other material culture will take some time and will need the support of more radiocarbon dates and larger scale excavations, but we have made an important start and demonstrated that significant morphological differences existed between the assemblages of different periods. Our studies of palaeoenvironment and of human and animal remains are at a very preliminary stage and have not been presented here. However, the potential for these data to significantly enhance our knowledge and understanding of the historic societies of the Draa should not be underestimated.

The project has also served to demonstrate the vulnerable state and endangered status of many sites of historical importance. In the Middle Draa valley modern development is intensifying, involving increased construction of buildings and infrastructure such as roads, canals and rubbish dumps. Some archaeological sites have been looted or robbed to obtain material for building, or demolished to make way for new structures. Increasing development has damaged archaeological sites and continues to threaten others. Recording sites through survey and excavation will not only allow a record of them to be made before they are destroyed, but will also support the development of measures designed to protect them. The Moroccan-U K Middle Draa Project is working with local agencies responsible for tourism and heritage, regional, and local government to evaluate and protect the cultural heritage from its various risks and to encourage proactive decisions on preservation measures for key sites like Zagora. Arising from this we have also prepared a proposal for creating a protected zone around the key sites of ZAGoo1/ZAGoo2 and the preIslamic mound cemetery of ZAGoo7 (Fig. 22).

\section{Acknowledgements}

Funding for the MDP fieldwork was primarily from the European Research Council grant for the Trans-Sahara Project (Grant no: 269418); Louise Rayne's participation was supported by the Endangered Archaeology of the Middle East and North Africa Project, funded by the Arcadia Trust. After a reconnaissance trip to the region with Youssef Bokbot in January 2015, a formal accord was signed with INSAP and the first field season of three weeks took place in November 2015. The project is grateful to Dr Aomar Akerraz, Director of INSAP, for his support for the project. We also acknowledge the permissions granted to the project by the Directeur du Patrimoine Culturel, M. Abdellah Alaoui. Aziz Jilalo of the Zagora Maison de la Culture took a deep interest in our work and generously made available work space for our finds team and a store for our finds and equipment. For the adminsitrative and security clearances for our project and much additional help we must thank the Governorat de la Province de Zagora, the Colonel Chef du District Militaire de Tagounit, the Ministry of Tourism (in particular Ahmed Chahid et Mahjoub Aarab), the Associations de Développement Culturel et Protection de l'Environment de Zagora and Adil Moumane, a teacher of Geology and Biology in Zagora. At the University of Leicester, we need to acknowledge the assistance of Danielle de Carle, Oliver Dooley, B. Tyr Fothergill, Mark Gillings, Richard Griffiths, Victoria Lucas, Andy Tams, Richard Thomas, Adam Thuraisingam and Ian Whitbread. Finally, we must thank the financial and scientific officers at the ERC responsible for the TransSahara Project (Frederic Cimeniac and Cecile MenetreyMonchau) and our colleagues in the EAMENA Project at Oxford, notably Andrew Wilson and Robert Bewley. 
The personnel in the field were:Youssef Bokbot, Aurélie Cuénod, Corisande Fenwick, Maria Carmela Gatto, Katrien Janin, Andrew Lamb, David Mattingly, Niccolò Mugnai, Julia Nikolaus, Nick Ray, Louise Rayne and Martin Sterry, with Abdallah Fili due to study the Islamic glazed pottery post-season.

\section{References}

Bokbot, Y. 1991. Habitats et monuments funéraires du Maroc protohistoriques. Thèse de Doctorat. Université d'Aix-enProvence.

Bokbot, Y., Onrubia-Pintado, J., Rodriguez-Rodriguez, A., Rodriguez-Santana, C.G., Velasco-Vazquez, J. \& Amarir, A. 2005. Le complexe funéraire et culturel d'Adrar Zerzem (AntiAtlas, Maroc). Resultats préliminaires. Études d'Antiquites africaines - Lieux de cultures - IX colloque international (Tripoli). CNRs Éditions, Paris, pp. 21-29.

Bonine, M.E. 1990. The sacred direction and city structure: a preliminary analysis of the Islamic cities of Morocco. Muqarnas $7,5^{0-72 .}$

Camps, G. 1984. Rex gentium Maurorum et Romanorum. Recherches sur les royaumes de Maurétanie des $\mathrm{VI}^{\mathrm{e}}$ et $\mathrm{VII}^{\mathrm{e}}$ siècles. Antiquités africaines 20, 183-218.

Capel, C. forthcoming. At the Dawn of Sijilmasa: New historical focus on the process of emergence of a Saharan state and a caravan city. In: Sterry, M. and Mattingly, D.J. (eds.), Urbanisation and State Formation in the Ancient Sahara and Beyond. Trans-Sahara Archaeology Vol. 4 (Series Editor D.J. Mattingly). Cambridge: Cambridge University Press and Society for Libyan Studies.

Cressier, P. \& Fentress, E. 2010. La céramique maghrébine du haut moyen age (VIII ${ }^{e_{-}}{ }^{e}$ siècle). État des recherches, problèmes et perspectives. École francaise de Rome, Rome.

di Lernia, S., Tafuri, M.A., Gallinaro, M., Alhaique, F., Balasse, M., Cavorsi, L., Fullagar, P.D, Mercuri, A.M., Monaco, A., Perego, A. \& Zerboni, A. 2013. Inside the "African Cattle Complex": Animal burials in the Holocene Central Sahara. PLOS ONE 8(2), e56879. doi:10.1371/journal.pone.0056879

Eve, S. \& Hunt, G. 2008. ARK: A developmental framework for archaeological recording. In: Posluschny, A., Lambers, K. \& Herzong, I. (eds.), Layers of Perception: Proceedings of the 35th International Conference on Computer Applications and Quantitative Methods in Archaeology (CAA), Berlin, Germany, April 2-6, 2007. Rudolf Habelt, Bonn.

Glory, A., Allain, C. \& Reine, M. 1955. Les gravures rupestres libyco-berbères du Haut Draa (Maroc). In : Balout, L. (ed.), Actes $d u 2^{\text {ème }}$ Congrès Panafricain de Préhistoire, Alger, 1952. Arts et Métiers Graphiques, Paris, pp. 715-722.
Jacques-Meunié, D. 1958. La necropole de Foum el-rjam, tumuli du Maroc presaharien. Hesperis 35, 95-142.

Jacques-Meunié, D. 1982. Le Maroc saharien des origins à 1670 . 2 vols. Klincksieck, Paris.

Kölbl, O., Boussahl, M. \& Hostettler, H. 2003. Requirements in an inventory on cultural heritage in Morocco and reflections on the presentation of the information. In: Orhan Altan, M. (ed.), Proceedings of the XIXth International Symposium, CIPA 2003: New Perspectives to Save Cultural Heritage, CIPA, Istanbul, Turkey, 3oth September-o4th October 2003. CIPA, Istanbul, pp. 25-28.

Letan, R. 1972. Note sur un gisement acheuléen de surface de la region du Draa. Bulletin d'Archéologie Marocaine 8, 1-2.

Lihoreau, M. 1993. Djorf Torba, nécropole saharienne antéislamique. Karthala, Paris.

Margat, J. \& Camus, A. 1958-59. La nécropole de Bouïa au Tafilalt. Bulletin d'Archéologie Marocaine 3, 63-74.

Marmol Carvajal, L. 1573. Primera parte de la descripcion general de Affrica: con todos los successos de guerras que a audio entre los infieles, y el pueblo Christiano, y entre ellos mefmos desde que Mahoma inuéro su seçta; hasta el ano del fenor mil y quinientos y setenta y uno. Dirigida a la. C.R.M. del Rey Don Phelippe Segundo deste nombre. Granada.

Mattingly, D.J. (ed.). 2003. The Archaeology of Fazzan. Volume 1, Synthesis. Society for Libyan Studies, Department of Antiquities, London.

Mattingly, D.J. (ed.). 2007. The Archaeology of Fazzan. Volume 2, Site Gazetteer, Pottery and other Survey Finds. Society for Libyan Studies, Department of Antiquities, London.

Mattingly, D.J. (ed.). 2010. The Archaeology of Fazzan. Volume 3, Excavations carried out by C.M. Daniels. Society for Libyan Studies, Department of Antiquities, London.

Mattingly, D.J. (ed.). 2013. The Archaeology of Fazzan. Volume 4, Survey and Excavations at Old Jarma (Ancient Garama) carried out by C.M. Daniels (1962-69) and the Fazzan Project (1997-2001). Society for Libyan Studies, Department of Antiquities, London. Mattingly, D.J., Sterry, M. \& Ray, N. forthcoming. Dying to be Garamantian. In: Gatto, M.C., Mattingly, D.J. Ray, N. and Sterry, M. (eds.), Burials, Migration and Identity in the Ancient Sahara and Beyond. Trans-Sahara Archaeology Vol. 2 (Series Editor D.J. Mattingly). Cambridge: Cambridge University Press and Society for Libyan Studies.

Messier, R.A. \& Miller, J.A. 2015. The Last Civilized Place: Sijilmasa and its Saharan Destiny. University of Texas Press, Austin.

Meunié, J. \& Allain, C. 1956. La forteresse almoravide de Zagora. Hesperis 43, 305-324.

Morizot, P. 1997. Archéologie aérienne de l'Aurès. ВСтH, Paris. Mouttaqi, A., Rjimati, E., Maacha, A., Michard, A., Soulaimani A. \& Ibouh, H. 2011. Les principales mines du Maroc. Éditions du Service Géologique du Maroc, Rabat. 
Pichler, W. 2000. The Libyco-Berber inscriptions of Foum Chenna/Morocco. Sahara 12, 176-178.

Reygasse, M. 1950. Monuments funéraires préislamiques de l'Afrique du Nord. Arts et Métiers Graphiques, Paris.

Rosenberger, B. 1970. Les vielles exploitations minières et les centres métallurgiques du Maroc; essai de carte historique (1ère partie). Revue de géographie du Maroc 17, 71-108.

Simoneau, A. 1972a. Les prospections rupestres dans la région du Draa (Extrême Sud marocain), Avril 1971-avril 1972. Almogaren 3, 15-31.

Simoneau, A. 1972b. Nouvelle gravures rupestres du haut-Atlas et du Draa. Bulletin d'Archéologie Marocaine 8, 2-39.
Sterry, M. \& Mattingly, D.J. 2011. Desert Migrations Project XIII: Reconnaissance Survey of archaeological Sites in the Murzuq Area. Libyan Studies 42, 103-116.

Sterry, M. \& Mattingly, D.J. 2013. Desert Migrations Project XVII: further AMS dates for historic settlements from Fazzan, South-West Libya. Libyan Studies 44, 127-140.

Sterry, M., Mattingly, D. J. \& Higham, T. 2012. Desert Migrations Project XVI: radiocarbon dates from the Murzuq region, Southern Libya. Libyan Studies 43, 137-147.

Zaïnabi, A.T. (ed.). 2004. Trésors et merveilles de la vallée du Drâa. Ed Marsam, Zagora. 